Toplum Bilimleri Dergisi - Journal of Social Sciences

ISSN: 1306-7877 e-ISSN: 2147-5644

Haziran / June 2019, 25 : 89-120

\title{
Güney Bavyera'daki Türkçe Anadili Dersi ve Türkçe Öğretmenleriyle İlgili Paradigmatik Bir Değerlendirme
}

A Paradigmatic Study about Turkish Native Language Courses and Turkish Teachers in Southern Bavaria

\section{Mustafa ÇAKIR}

Prof. Dr., Türkiye Cumhuriyeti Münih Başkonsolosluğu Eğitim Ataşesi Prof.Dr., Education Attache of the Republic of Turkey, Consulate in Munich

Munich, Germany mcakir@anadolu.edu.tr

\section{Makale Bilgisi / Article Information}

http://dx.doi.org/10.29228/tbd.2007.25.1427

Makale Türü / Article Types: Araştırma Makalesi / Research Article

Geliş Tarihi / Received: 17 Mayıs / May 2019

Kabul Tarihi / Accepted: 19 Haziran / June 2019

Yayın Tarihi / Published: 23 Haziran / June 2019

Yayın Sezonu / Pub Date Season: Haziran / June

Cilt / Volume: 25

Sayfa / Pages: 89-120

Copyright @ Published by Toplum Bilimleri Dergisi - Journal of Social Sciences.

All rights reserved. www.toplumbilimleri.com 


\section{Güney Bavyera'daki Türkçe Anadili Dersi ve Türkçe Öğretmenleriyle İlgili} Paradigmatik Bir Değerlendirme

Öz: Almanya Federal Cumhuriyeti ile 1961 yılında imzalanan iş gücü anlaşmasının ardından ülkedeki işçi çocuklarının eğitimi için de bir dizi önlemler alınmış ve uygulamaya koyulmuştur. 1973 yılında Türkçe derslerine başlanmıştır. MEB da 1977 yılında yurt dışı teşkilatını kurmuş ve eğitim ataşeliklerini oluşturmuş; Türkiye'den Bakanlıklararası Ortak Kültür Komisyonu (BAOKK) üzerinden öğretmen görevlendirmeleri yapmıştır. Bavyera'daki okullarda Türkçe anadili derslerinin yanı sıra çocuklara Almanca kursları ve ülkelerine döndüklerinde kendi okul sistemine uyum sağlayabilmelerini teminen Türkçe alan dersleri verilmeye başlanmıştır. Almanca bilgisi iyi olanlar Türkçe sınıflardan Almanca eğitim verilen sınıflara da geçebilme imkânına sahip olmuştur. Bu uygulama 2004 yılına kadar devam etmiştir. Bavyera Eyaleti Hükümeti [Bayerische Regierung] 14 Eylül 2004 tarihinde aldığı yeni bir karar ile bu derslerin verilmesini Başkonsolosluğun uhdesine bırakmış; bu dersin beş sene içinde okullardan kademeli olarak çıkarılması kararını almıştır. Bu karara karşı, 2004 yılında düzenlenen kampanya sonunda 38.700 imza toplanmasına karşın, sonuç alınamamıştır. Bavyera Eyaleti Hükümetinin [Bayerische Regierung] aldığı bu karar, 2009 yılından bu yana uygulanmaktadır. Buna göre; Hırvat, Portekiz, Macar, İtalyan, İspanyol ve Türkiye kökenlilere için tek tip bir uygulama yapmaktadır. Bu uygulama çerçevesinde ilgili ülkelerin konsoloslukları tarafından hazırlanan başvuru formları ve dilekçeler bakanlığın ilgili birimleri tarafından il eğitim müdürlükleri üzerinden bütün okullara bir genelge ile dağıtılmakta ve okullarda biriken başvuru dilekçeleri, okul yöneticileri tarafından başkonsolosluklara toplu olarak gönderilmekte ve bu okullardaki talebe göre öğretmen istihdamı sağlanmaktadır. Halen Türkiye Cumhuriyeti Münih Başkonsolosluğu Eğitim Ataşeliği görev bölgesi olan Güney Bavyera illerinde (Oberbayern, Niederbayern und Schwaben) 41 Türkçe ve Türk Kültürü (TTK) dersi öğretmeni görev yapmaktadır. Türkçe ve Türk Kültürü (TTK) derslerine katılan öğrenci sayısı 15 Aralık 2018 tarihi itibari ile 232 okul ve dört ayrı Sivil Toplum Kuruluşlarında olmak üzere toplam 2614'tür. 2018/2019 eğitim öğretim yılında çalışmakta olan Türkçe ve Türk Kültürü Dersi öğretmeni sayısı toplam 41 kişi olup, öğretmen başına düşen öğrenci sayısı ise 65, okul sayısı $5,6^{\prime}$ dir.

Anahtar Kelimeler: Türkçe, anadili dersi, Türkçe anadili dersi, işgücü anlaşması, Türkçe öğretmeni, yurt dışı Türkçe öğretmeni 


\section{A Paradigmatic Study about Turkish Native Language Courses and Turkish}

\section{Teachers in Southern Bavaria}

Abstract: After the employment contract was signed in 1961 with the Federal Republic of Germany, a series of measures to educate workers' children in the country were taken and implemented. Turkish courses began in 1973. In 1977, the Ministry of National Education established its foreign organizations and opened the Education Units in the Consulate General. Teachers from Turkey were transferred abroad via the Interministerial Culture Commission. The Bavarian schools offered Turkish language courses as well as German courses for immigrant children so that they could adapt to their own school system when they returned to their countries. Those with good knowledge of German had the opportunity to move from the Turkish classes to the German-speaking rule classes. This was continued until 2004. On 14 September 2004, the Bavarian government took a new decision to phase out Turkish schools within five years and to hand over Turkish language courses to the Consulate General. As a result, in 2004 a campaign collected 38,700 signatures to reintroduce Turkish language courses, but ranked at the Ministry but did not produce any positive results. The decision of the Bavarian government came into force in 2009. It is a uniform application for Croatian, Portuguese, Hungarian, Italian, Spanish and Turkish origin. Under this decision, the application forms prepared by the consulates of the countries concerned will be distributed to all schools through the provincial governing bodies from the relevant departments of the ministry, and the forms collected at the schools will be sent by the school administrators to the Consulate General and the hiring of teachers will be done according to the demand in these schools. In the federal states of Southern Bavaria (Upper Bavaria, Lower Bavaria and Swabia), which is still responsible for the education system of the Republic of Turkey at the consulate in Munich, there are currently 41 Turkish and Turkish cultural teachers. The number of students participating in the Turkish and Turkish Culture (TTK) will be 2,614 in the total of 232 schools and four separate non-governmental organizations as of 15 December 2018. For the 2018/2019 school year, the number of Turkish and Turkish cultural teachers is 41 , the number of pupils per teacher is 65 , and the number of schools is 5.6.

Keywords: Turkish, native language courses, Turkish native language courses, labor agreement, Turkish teacher, Turkish teachers abroad 
Mustafa ÇAKIR - Güney Bavyera' daki Türkçe Anadili Dersi ve Türkçe Öğretmenleriyle İlgili Paradigmatik Bir Değerlendirme

\section{GíRiş}

Ortada bir sorun varsa, bu sorunun çözümü kuram ile olmaz; aksine kuram sorunu görmezden gelir. Sorunlar büyüdüğünde ise pragmatik çözümler üretmek gerekir. Bu durumda paradigma olgusu ortaya çıkar. Paradigma, bir modelin bir bakış açısının kavrayışın, onu anlamlandırmanın adıdır. Bu çalışmada kullanılan paradigma kavramı "bir kimsenin bir sorunu çözerken ya da bir görevi yaparken baş vurduğu bakış açısı, daha genel olarak söylemek gerekirse bir mantığı yürütürken kullandığı görüş açısı, değerler dizgesi" olarak tanımlanmıştır (TDK Türkçe Sözlük). Yönetim açısından bakıldığında ise yöneticilerin bir dizi kurallara bağlı olarak kendi yönetsel eylemlerini oluşturduğu yeni değerler dizgesi söz konusu olabilir. Bilimsel ve toplumsal gelişmeler de yeni paradigmaların, bakış açılarının ortaya çıkmasına zemin hazırlar. İşte bu anlamda paradigmalar; bilim topluluğu için üzerinde durulması gereken önemli konuları belirler ve sorun olarak gördüğü konuların çözümü için yöntem ve teknikler sunar (Fırat 2008).

Bavyera Eyaleti de ülkede yaşayan yabancıların çocuklarının okul sistemi içindeki sorunlarını tespit etmiş ve çözümü için ülkedeki yabancı misyon temsilcileri ile işbirliği yapmış; kabul edilebilir yöntem ve teknikleri geliştirip uygulamıştır. Zaman içinde bu mevcut uygulamanın etkisini kaybettiği ve yabancı kökenli çocukların okullarında istenen akademik başarıya ulaşamadıkları kanaatine varılması üzerine, neden sonuç ilişkisi kurarak yeni bir model uygulamaya karar vermiş ve uygulamaya geçirmiştir.

$\mathrm{Bu}$ çalışmada Bavyera Eyaleti Hükümeti [Bayerische Regierung] ve Türkiye Cumhuriyeti Devleti tarafından yabancı/Türk işçi çocuklarının eğitimi konusunda alınan tedbirler tarihi süreci içinde analiz edilmiş; günümüzdeki duruma ilişkin karşılıklı bakış açıları, paradigmalar, üzerinde durulmuştur.

30.09.2017 tarihi itiarı ile 12.988539 nüfusu olan Bavyera Eyaletinin Münih'te yayınlanan 2018 Uyum Raporu'na göre Bavyera eyaletinin başkentinde yaşayan göçmenler arasında Türk vatandaşları ilk sırada yer almaktadır. Dolayısı ile yabancılara yönelik uygulamalar söz konusu olduğunda ilk akla gelenler de Türkler olmaktadır. Çünkü eyaletteki yabancıların yüzde 40'ını Türkler, yüzde 24,2'sini Yunan vatandaşları ve yüzde 
Mustafa ÇAKIR - Güney Bavyera' daki Türkçe Anadili Dersi ve Türkçe Öğretmenleriyle İlgili Paradigmatik Bir Değerlendirme

24'ünü de Hırvatlar oluşturmaktadır. 2009 yılı sonunda Münih'te 309 bin yabancı yaşarken, 2012 yılı sonu itibariyle yabancıların sayısının 354 bine çıktığı tespit edilmiştir. ${ }^{1}$

Federal Göç ve Mülteciler Dairesi'nin verilerine göre Almanya'da yaşayan “Türkiye kökenlilerin"² sayısı yaklaşık 2 milyon 900 bin kişidir. Dairenin yayımladı̆̆ı verilere göre 2014 yılında 22 binden fazla Türkiye kökenli göçmen Alman vatandaşlığına geçmiştir. Bu sayı Almanya Federal Cumhuriyeti vatandaşlığına geçenlerin tamamının beşte birini oluşturmaktadır³.

Eyalette 2016/2017 eğitim öğretim yılında 49.866 yabancı (uluslararası) öğrenci yüksek öğrenim görmektedir. Bunlardan 10.990 öğrenci Bildungsinländer (yani yabancı pasaportlu olup, üniversite öğrenim yeterliliğini Almanya'da almış olanlar). 34553 öğrenci ise Bildungsausländer (yabancı bir ülkeden yükseköğrenim görmek için Almanya'ya gelen ve geldiği ülkede yükseköğrenim görme hakkı kazanmış olan). 4.323 kişi de üniversite öğrenim yeterliliğini yurt dişındaki bir eğitim kurumunda almış olup, Almanya'ya yükseköğrenim görmek üzere gelen Alman vatandaşından oluşmaktadır

\begin{tabular}{|l|l|l|l|}
\hline Okul Türü & Genel & Yabanci & Türk \\
\hline Anasınıfı & -- & -- & - \\
\hline Ilkokul & 634.353 & 89.795 & 2.070 \\
\hline Ortaokul & 218.819 & 9.326 & 2.585 \\
\hline Lise & 317.405 & 13.915 & 969 \\
\hline Meslek Lisesi & 430.937 & 49.183 & 7.973 \\
\hline Genel Toplam & 1.601 .514 & 162.219 & 13.597 \\
\hline
\end{tabular}

Tablo 1: 2017/2018 Eğitim Öğretim Yılı Öğrenci Sayılarının Dağılım ${ }^{5}$

2014/2015 eğitim öğretim yılında Bavyera'da öğrenim gören Türk öğrenci sayısı toplam 25.437. Türk öğretmen sayısı ise 46 kişidir. Bu okullardan diploma ile mezun

\footnotetext{
${ }^{1}$ Emlak Kulisi. Münih Türk nüfusu. Bilgiye, https://emlakkulisi.com/guncel/munih-turk-nufusu/619160 adresinden 20.07.2018 tarihinde erişildi.

${ }^{2}$ Burada kullanılan Türkiye kökenli ifadesi bilinçli ve siyasal anlam içeren bir tercihtir.

3 DW. Almanya'daki Türkiye kökenlilerin sayısı açıklandı. Bilgiye, https://www.dw.com/tr/ adresinden 20.07.2018 tarihinde erişildi.

${ }_{4}^{4}$ Bavyera İstatistik Dairesi Basın Bülteni (16.11.2017) https://www.statistik.bayern.de/presse/archiv/282 2017.php adresinden 20.07.2018 tarihinde erişildi.

5 Çizelgedeki sayısal veriler Eğitim Ataşeliği personeli Uzm. Gonca Onal tarafından Bavyera İstatistik Dairesi (www.statistik.bayern.de) verilerinden derlenmiştir.
} 
Mustafa ÇAKIR - Güney Bavyera' daki Türkçe Anadili Dersi ve Türkçe Öğretmenleriyle İlgili Paradigmatik Bir Değerlendirme

olanların sayısı ise 9.431 kişi iken 2018/2019 eğitim öğretim yılı istatistiklerine göre eyalette 13.597 Türk öğrenci kaydı bulunmaktadır ${ }^{6}$.

\begin{tabular}{|l|l|}
\hline Eğitim Durumu & Öğrenci Sayısı \\
\hline Ön Lisans & --- \\
\hline Lisans & 3.527 \\
\hline Yüksek Lisans & 782 \\
\hline Doktora & 125 \\
\hline
\end{tabular}

Tablo 2: 2017/2018 Eğitim Öğretim Yılı Öğrenci Sayılarının Dağılımı7

Üniversite düzeyinin altında okula giden öğrencilerin durumuna gelince, 2014/2015 öğretim yılı başındaki yabancı uyruklu öğrenci sayısı 135.128. En kalabalık öğrenci sayısını \% 18,8 ile Türk öğrenciler oluştururken, bunları takip eden Yunan öğrecilerin oranı \% 6,2. İtalya \% 6 ve Kosova \% 5,2'dir. Öğrenci sayılarının giderek azalmasının nedeni, halen uygulanmakta olan vatandaşlık yasasından ve istatistik dairelerinin kökenlere göre ayırım yapmamasından kaynaklanmaktadır. Yasaya göre Almanya'da doğan çocuklar belli şartları sağlamak kaydı ile Alman vatandaşlığını alıyor ve istatistiklerde Türk olarak gösterilmiyor.

Son rapora göre göçmenlerin eğitim durumlarında düzelme olduğu görülmektedir. 2007 yılında Gymnasium okuluna giden göçmen çocuklarının oranı yüzde 26'dan 2011 yılında yüzde 32'ye ve Realschule okullarına giden öğrencilerin oranının da aynı dönem de yüzde 13'den yüzde 19'a çıkmıştır. 2012 yılında 0 - 6 yaş arası göçmen çocuklarının sayısı Münih'te 43.000 binken, Alman çocuklarının oranları 36.000 olarak kayıtlara geçmiştir.

\section{TTK DERSINIIN GÜNEY BAVYERA'DAKİ TARİHÇESİ}

Bavyera Eyaleti ülkede bulunan yabanc1/misafir işçi çocuklarının eğitim öğretimi konusunda öngörülü olan ve bu öngörüler çerçevesinde tedbirler alan bir anlayışa sahiptir. Aldıkları kararların uzun süreli uygulanmasına ve süreç analizi yapılmasına da özen gösterilmektedir. Aşağıda Almanya genelinden başlayıp, Bavyera Eyaleti özelindeki

\footnotetext{
${ }^{6}$ Bavyera İstatistik Dairesi. Statistische Berichte - B02003 201400 - Ausländische Schüler und Lehrer an den bayerischen Schulen 2014/15, s. 13 .

7 Çizelgedeki sayısal veriler Eğitim Ataşeliği personeli Uzm. Gonca Onal tarafından Bavyera İstatistik Dairesi (www.statistik.bayern.de) verilerinden derlenmiştir.
} 
Mustafa ÇAKIR - Güney Bavyera'daki Türkçe Anadili Dersi ve Türkçe Öğretmenleriyle İlgili Paradigmatik Bir Değerlendirme

uygulama sözlü tarih uygulaması tekniği kullanılarak (kaynak arama, sınıflandırma, çözümleme, eleştiri ve verilerin analizi) ortaya koyulmuştur. Özellikle Türkçe ve Türk Kültürü Dersi ile ilgili bilgi kirlenmesinden söz edilen bir dönemde, bu bilgilerin verilmesinin sorunun anlaşılmasına katkı sağlayacağı düşünülmektedir.

\section{Almanya Açısından Süreç Analizi}

Türkiye Cumhuriyeti ile Almanya Federal Cumhuriyeti arasında işgücü anlaşması 30 Ekim 1961 tarih ve 505-83 SZV/3-92-42 sayılı Almanya Federal Cumhuriyeti Hükümetinin iş arayan Türk vatandaşların AFC'ndeki işverenler nezdinde bir işe yerleştirmeyi teklif eden notasının kabul edilmesiyle, önceyi kapsayacak şekilde 1 Eylül 1961'den itibaren bir yıl için yürürlüğe girmiştir. Ardından 19 Mayıs 1964 tarihde Bonn'da yapılan heyetler arası görüşmede uygulamada ortaya çıan hususlarla ilgili görüşmeler yapılmış, ilave maddeler koyulmuştur. Bu görüşmede Federal Dışş̧leri Bakanlığının Türkiye'nin Bonn Büyükelçiliğine verdiği "10 Mart 1964 tarihli notasına temasla, Türkiye Cumhuriyeti Münih Başkonsolosluğunun esasen ikamet müsaadesi bulunan aile reislerinin münferit pasaportlarına ailenin diğer fertlerini de aktarmak suretiyle, bunların da kendisine verilmiş bulunan ikamet ve çalı̧̧ma müsaadesinden istifade ettirilmesi yönüne gittiğini" bildirmekle, ilk defa aile bireyleri gündeme gelmiş; ancak taraflarca ne iş̧̧ilerin ne de aile fertlerinin eğitimine ilişkin bir husus gündeme getirilmiştir.

Almanya Kültür Bakanları Konferansı [Die Ständige Konferenz der Kultusminister der Länder in der Bundesrepublik Deutschland] 14-15 Mayıs 1969 ve 3 Aralık 1971 yılında aldığı kararlar ile ülkedeki yabancı çocuklarının eğitimi için uygun tedbirlerin alınmasını kararlaştırmıştır ${ }^{8}$. Bu uygulama ile çocukların anadili bilgisini muhafaza etmesi ve geliştirmesi ile ülkelerine döndüklerinde kendi okul sistemine uyum sağlayabilmesi, dil ve kimliklerini muhafaza edebilmeleri amaçlanmıştır.

Uygulamada, yabancı çocukların okulda Alman çocukları ile eşit muamele görmeleri ve bir derslikteki [Regelklasse] sayılarının toplam öğrenci sayısının 1/5'ini geçmemesi, dil güçlüğü olanlara ilave Türkçe ve Almanca yardımcı ders verilmesi kararlaştırılmıştır. Bu arada Türkçe hazırlık sınıfında verilen derslerin içerik olarak Alman öğrencilere verilen derslerle aynı olmasına özen gösterilmesine ve en fazla 25 öğrenciden oluşacak bu sınıflarda verilen derslerden Almana dil dersi dışında kalanların yabancı öğretmenlerce verilmesi

\footnotetext{
8 Sekretariat der Ständigen Konferenz der Kultusminister der Länder in der Bundesrepublik Deutschland (Yay.) Beschlüsse der Kultusministerkonferenz: Unterricht für Kinder ausländischer Arbeitnehmer. Neuwied: Hermann Verlag, 1981 , s. 1.
} 
ilkesi benimsenmiştir. Yoğun Almanca takviye dersi de verilen bu öğrencilerden akademik başarısı iyi olanların Alman öğrencilerin devam ettiği sınıflara [Regelklasse] geçmesi imkânı da sağlanmıştır. Alman öğrenciler ile aynı sınıfa devam ettiği için anadili dersi alamayan öğrenciler için de anadili ve kültürü tamamlama dersi [Muttersprachlicher Ergänzungsunterricht] verilmesi öngörülmüştür. Türkçe ve Türk Kültürü Dersi bu kararla açılmaya başlanmıştır. Bu dersleri verecek öğretmenlerin de kaynak ülkede öğretmenlik eğitimi almış kişilerin arasından seçileceği ve bunların Almanca öğrenmeleri karara bağlanmıştır. Bu derslerle ilgili olarak da ilgili ülkelerin Almanya'daki temsilcilikleri ile işbirliği yapılması karara bağlanmıştır.

Bu bağlamda Freising Bölgesi Eğitim Müdürlüğü 11.07.1973 ve 22.10.1973 tarihlerinde dönemin Başkonsolosluğuna yazdığı iki ayrı yazı ile Oberbayern Bölgesinde Türkçe anadili dersi açılması talebini iletmiş; Türkiye'de Milli Eğitim Bakanlığı ilköğretim müfettişi olarak görev yaparken Almanya'ya gelmiş olan öğretmen Ruşen Ünal'ın da Türkçe öğretmeni yeterliliğine sahip olup olmadığını da gönderilen yazıların ekine koyulan diploma ve diğer belgeleri ile sormuştur ${ }^{9}$. Bu dersin açılmasıyla ilgili yasal dayanağı da Bavyera Eyaleti yerel mevzuatı açısından şu şekilde açıklamıştır ${ }^{10}$ :

17 Kasım 1966 tarihli (GVBl.) S. 402) İlkokul Kanunun [Volksschulgesetzes (VoSchG)] 25. Maddesinin birinci (1) paragrafının 5. Bendi, 29. Maddesinin 5. Bendi, halen yürürlükte olan değişik 27 Haziran 1972 (GVBl. S. 214) tarihli kanunun 2., 9., 11inci maddeden 15. maddeye kadar kısmı, özellikle 9 Mart 1960 tarihli Bavyera Eğitim Öğretim Kanununun yürürlükte olan 15 Haziran 1972 (GVBl s. 19) tarihiyle değişik 18. Maddesi.

Bavyera Eyaleti Eğitim, Kültür, Bilim ve Sanat Bakanlığı tarafından yayımlanan Tebliğler Dergisi [Amtsblatt] 7 Aralık 1989 tarihli 9 numaralı özel sayısında (s. 277) 28 Eylül 1989 tarih ve 111/4 - 4/92748 nolu kararı ile kabul edilen Yabancı Öğrenciler İçin Anadili Kültür Dersleri Müfredat Programını yayımlamıştır. Bu müfredat Bavyera Temel Eğitim Yönetmeliğinin 10. Paragraf ve 5. Maddesine göre temel eğitimin 1. ve 2. devresi Anadili Kültür Dersleri, Ortaokul yönetmeliğinin 1a C bölümüne göre ortaokul seçmeli Anadili Kültür Dersleri ve bunun gibi 29 Ağustos 1984 tarihli Eğitim ve Kültür Bakanlığı (KMBI I s. 510) Resmi yayınının 4.2.3 numarasına göre liselerde Anadili Kültür Dersleri için 1990/91 eğitim öğretim yılından itibaren uygulanmasına karar verilmiştir.

\footnotetext{
9 Türkçe öğretmenimiz Ruşen Ünal emekli olmuş; halen ailesi ile Münih’te yaşamaktadır. Kendisi ile Eğitim Ataşeliğinde yapılan görüşmede resmi belgelerdeki bilgiler de teyit edilmiştir. Oğlu da Müh. Dicle Ünal Münih Yabancı Veliler Derneği (Ausländischer Elternverein München e.V.) Başkanlığını yapmaktadır.

10 Kanunun özgün ifadesi: (Art. 25. Abs (1) Ziffer 5. Art. 29. Ziff. 5 des Volksschulgesetzes (VoSchG) vom 17. November 1966 (GVB1.) S. 402) in der Fassung 27. Juni 1972 (GVBl. S. 214) maddesinin ilgili olan (Art. 1. Abs. (2) Art. 2, 9, 11 bis 15, insbesondere Art. 18 des Gesetzes über das Erziuhungs- und Unterrichtswesen in Bayern (EUG) vom 9. März 1960 (GVB1 s. 19) in der Fassung vom 15. Juni 1972 (GVBl. S. 189).
} 
Türk çocuklarına Türkçe ve Türk Kültürü Dersinin (TTKD) verilmesi 2004 yılına kadar sorunsuz bir şekilde devam etmiştir. Bavyera Eyaleti Hükümeti [Bayerische Regierung] 14 Eylül 2004 tarihinde aldığı yeni bir karar ile bu derslerin verilmesini Başkonsolosluğun uhdesine bırakmış; bu dersin beş sene içinde kademeli olarak müfredattan çıkarılması kararını almıştır ${ }^{11}$. Alınan karar 01 Ekim 2004 tarihli bir yazı ile Müsteşar Dr. Erhard imzası ile dönemin Başkonsolosu Mustafa Babür Hızlan'a iletilmiştir. $\mathrm{Bu}$ karara gerekçe olarak, okuldaki yabancı uyruklu öğrencilerin Almanca dil yetersizliği nedeniyle akademik başarılarının istenen düzeyde olmaması, anadili derslerine verilen ağırlıktan kaynaklandığı gösterilmiştir. 2003/2004 eğitim öğretim yılında okul çağında olan 48.860 öğrenciye; okul öncesi yaştaki 2.761 çocuğa Almanca eğitim verildiği belirtilmiştir. Buna ilave olarak 2.000 öğrencinin 166 ayrı sınıfta Almanca kursuna kayıtlı olduğu bilgisi verilmiştir.

Bavyera Hükümeti 14 Ekim 2004 tarihinde aldığı bu gerekçeli karar ile köken dili dersi (Türkler için, Türkçe ve Türk Kültürü Dersi [Muttersprachlicher Ergänzungsunterricht]) için ayırdığı mali kaynağı Almanca için kullanmaya karar vermiş; 2004/2005 eğitim öğretim yılından itibaren Türkçe ve Türk Kültürü Dersinin [Muttersprachlicher Ergänzungsunterricht] beş yıl içinde kademeli olarak kaldırılacağını ve bu derslerin ilgili ülkelerin Konsolosluklarının sorumluluğuna bırakıldığını bildirmiştir.

1 Aralık 2004 tarihinde başlatılan kampanya sonunda 38.700 imza Bavyera Eğitim Bakanlığına verilmek istenmiş, bunun için Münih Yabancılar Meclisi Başkanlığının desteği ile bu uygulamadan etkilenen ülkelerden temsilciler seçilerek bir çalışma komisyonu oluşturulmuştur. Komisyon eyalet yönetiminin verdiği desteğin devam ettirilmesini sağlamak ve toplanan dilekçelerin teslim edilmesi amacıyla dönemin Eğitim Bakanı Monika Hohlmeier'den randevu talep etmişse de sonuç alınamamış; araya giren 2005 eyalet parlamento seçimleri sonunda yeni bakan Siegfried Schneider de komisyonun randevu talebine cevap vermemiştir. Bu gelişmeler üzerine 12 Temmuz 2005 tarihinde bir protesto mitingi düzenlenmişse de belediye tarafından verilen tarihin hafta içine denk gelmesi nedeniyle katılımcı sayısı beklenenden düşük olmuştur. Bakan Siegfried Schneider bu gelişmeler üzerine 03.08.2005 tarihine randevu vermiştir.

\footnotetext{
${ }^{11}$ Bazı ilkokullarda Türk ilkokul öğretmenleri tarafından, tamamen Türk çocuklarından oluşan Türkçe öğretim yapılan sınıflar oluşturulmuş; bu karar ile bu uygulamaya son verilmiştir. Dolayısı ile TTKD sadece müfredatta yer alan bir ders değil, Türkçe öğretim verilen sınıf uygulaması şeklinde de uygulanmıştır.
} 
Mustafa ÇAKIR - Güney Bavyera'daki Türkçe Anadili Dersi ve Türkçe Öğretmenleriyle İlgili Paradigmatik Bir Değerlendirme

Dönemin Münih Yabancılar Meclisi Başkanı Cumali Naz, Münih Türk Okul Aile Birliği Başkanı Hüseyin Delemen ile Kuzey ve Güney Bavyera Türk Dernekleri Koordinasyon Kurulları temsilcilerinin de aralarında bulunduğu 15 kişilik heyet anılan gün ve saatte Eğitim Bakanlığında hazır bulunmuşlar; heyeti Bakanlık Müsteşarı Ludwig Erhard ve Yabancı öğretmenlerden sorumlu bakanlık çalışanı Sn. Dr. Hans-Dieter Göldner karşılamış; Bakan Schneider ise işlerinin yoğunluğunu gerekçe göstererek verdiği randevuya gelmemiştir. Yabancılar Meclisi Başkanı Cumali Naz, bir ay önceden alınan randevuya gelinmemesinin hayal kırıklığı yarattığını belirtmiş; yaklaşık bir saat süren toplantıda anadilinin önemi üzerinde konuşulmuş; toplanan imzalar Sn. Erhard'a elden teslim edilmiştir. Bu girişimden de bir sonuç alınamamıştır.

25.03.2010 tarihinde Bavyera Eyaleti Eğitim ve Kültür Bakanlığında yapılan ve İtalya, İspanya, Portekiz, Türkiye, Hırvatistan, Bosna Hersek, Sırbistan, Çekya, Polonya, Romanya, Bulgaristan temsilcileri ile Bavyera Eyaleti temsilcilerinin katıldığı toplantıda konsolosluklar tarafından verilen anadili derslerinin uygulama esasları görüşülmüştür. $\mathrm{Bu}$ toplantıda sayılan ülkeler konsolos veya eğitim ataşesi düzeyinde temsil edilirken Türkiye Cumhuriyeti yerelden atanan mahalli kâtip tarafından temsil edilmiş ve halen geçerli olan uygulama esasları protokol ile karara bağlanmıştır. Bu protokole göre Türkçe dersleri iki şekilde verilmektedir; ortaokul nitelikli bitirme sınavında Türkçe [Muttersprache als Abschlussfach bei der Besonderen Leistungsfeststellung zum Enrerb des qualifizierenden Hauptschulabschlusses (QA)] ve konsolosluk dersi olarak Türkçe. Konsolosluk Türkçe derslerinin verilmesi işlemi de Bavyera Eğitim ve Kültür Bakanlığı ile işbirliği halinde duyurulacak, okul idareleri başvuru dilekçelerini konsolosluklara gönderecek, konsolosluklar da öğretmen görevlendirecektir. Derslik tahsisinde ilke olarak ücret talep edilmeyecek, ancak okulun işletme giderlerini üstlenen kurumun talep etmesi halinde, konu taraflar arasında görüşülerek karara bağlanacaktır. Münih Büyükşehir Belediyesi tarafından işletilen okullarda ders yapılabilmesi için belediye işletme giderleri talep etmekte olup, taraflar arasında bir uzlaşı sağlanamamıştır.

17.07.2015 ve 28.08.2015 tarihlerinde Münih Başkonsolosluğu Eğitim Ataşeliği tarafından Münih Büyükşehir Belediyesine yazılan ve dersliklerin ücretsiz tahsis edilmesi hususunun tekrar talep edilmesi üzerine, Belediye Başkanı Dieter Reiter tarafından 17.08.2015 tarihli cevabi yazıda, Bavyera Eyaleti Hükümetinin [Bayerische Regierung] 14.04.2009 tarihli yazısı ile Köken Dili Derslerinin eğitim öğretim faaliyetleri dışına alındığının teyit edildiği ve Belediyenin de Bavyera Yerel Yönetim Nizamnamesi [Gemeindeordnung-GO] 75. Maddesi uyarınca 02.07.2013 tarihinde eğitim-öğretim 
Mustafa ÇAKIR - Güney Bavyera' daki Türkçe Anadili Dersi ve Türkçe Öğretmenleriyle İlgili Paradigmatik Bir Değerlendirme

etkinlikleri dışındaki faaliyetlerden ücret alınması konusunda alınmış bir encümen kararının olduğu bilgisi tekrar edilmiştir. Bu karara göre, eğitim öğretim etkinlikleri dışında yapılan kültürel çalışmalar için ücret talep edilecek ve öğrenciler için de sigorta yaptırılması istenecektir ${ }^{12}$.

Günümüze gelince, Bavyera Eyaleti Hükümetinin [Bayerische Regierung] 2010 yılından bu yana benimsediği uygulamaya devam etmektedir. Buna göre eyalette bulunan Hirvat, Portekiz, Macar, İtalyan, İspanyol ve Türk kökenlilere için tek bir uygulama yapmaktadır. Bu uygulama çerçevesinde ilgili ülkelerin konsoloslukları tarafından hazırlanan başvuru formları ve dilekçeler bakanlığın ilgili birimler tarafından il eğitim müdürlükleri üzerinden bütün okullara bir genelge ile dağıtılmakta ve okullarda biriken başvuru dilekçeleri, ilgili okul yöneticileri tarafından başkonsolosluklara toplu olarak gönderilmektedir ${ }^{13}$. Bu sürecin sonunda da yeterli talep toplanan okullara öğretmen tahsisi yapilmaktadir.

\begin{tabular}{|c|c|c|c|}
\hline \multicolumn{2}{|c|}{ Gymnasium } & \multicolumn{2}{|l|}{ Realschule } \\
\hline $\begin{array}{l}\text { Geç başlayan yabancı dil } \\
\text { olarak Türkçe }\end{array}$ & $\begin{array}{l}\text { T.C. } \\
\text { Başkonsolosluğu' nun } \\
\text { seçmeli/isteğe bağlı dersi }\end{array}$ & $\begin{array}{l}\text { T.C. } \\
\text { Başkonsolosluğ } u^{\prime} \text { nun } \\
\text { seçmeli/isteğe bağlı dersi }\end{array}$ & $\begin{array}{l}\text { T.C. } \\
\text { Başkonsolosluğu' nun } \\
\text { seçmeli/isteğe bağlı dersi }\end{array}$ \\
\hline $\begin{array}{l}\text { 10. sınıfta doğrudan, } 11 . \\
\text { sınıfta giriş/seviye tespit } \\
\text { sinavı ile geçiş } \\
\text { mümkündür. }\end{array}$ & 5. sinıftan 10. sinıfa kadar & $\begin{array}{l}\text { 5. siniftan } 10 . \quad \text { sinifa } \\
\text { kadar }\end{array}$ & $\begin{array}{lll}5 . \quad \text { siniftan } 10 . & \text { sinifa } \\
\text { kadar } & & \end{array}$ \\
\hline $\begin{array}{l}\text { ABITUR sınavında } \\
\text { Türkçe dersini sözlü } \\
\text { sinav yapılan ders olarak } \\
\text { seçmek mümkündür. }\end{array}$ & $\begin{array}{l}\text { Karnede sınıf geçmeye } \\
\text { etki eden not olarak } \\
\text { değerlendirilmez. Derse } \\
\text { katılım belgelendirilir. }\end{array}$ & $\begin{array}{l}\text { Karnede sınıf geçmeye } \\
\text { etki eden not olarak } \\
\text { değerlendirilmez. Derse } \\
\text { katılım belgelendirilir. }\end{array}$ & $\begin{array}{l}\text { Karnede sınıf geçmeye } \\
\text { etki eden not olarak } \\
\text { değerlendirilmez. Derse } \\
\text { katılım belgelendirilir. } \\
\text { Quali sınavına } \\
\text { Türkçeden girilebilir. }\end{array}$ \\
\hline $\begin{array}{l}\text { Dersin açılabilmesi için } \\
12 \text { velinin dilekçe } \\
\text { vermesi gerekir. Farklı } \\
\text { okullardan gelen talepler } \\
\text { de tek bir okulda ders } \\
\text { açılması için yeterlidir. }\end{array}$ & $\begin{array}{l}\text { Dersin açılabilmesi için } \\
12 \text { velinin dilekçe } \\
\text { vermesi gerekir. Farklı } \\
\text { okullardan gelen talepler } \\
\text { de tek bir okulda ders } \\
\text { açılması için yeterlidir. }\end{array}$ & $\begin{array}{l}\text { Dersin açlabilmesi için } \\
12 \text { velinin dilekçe } \\
\text { vermesi gerekir. Farklı } \\
\text { okullardan gelen talepler } \\
\text { de tek bir okulda ders } \\
\text { açılması için yeterlidir. }\end{array}$ & $\begin{array}{l}\text { Dersin açılabilmesi için } \\
12 \text { velinin dilekçe } \\
\text { vermesi gerekir. Farklı } \\
\text { okullardan gelen talepler } \\
\text { de tek bir okulda ders } \\
\text { açılması için yeterlidir. }\end{array}$ \\
\hline $\begin{array}{l}\text { Geç başlayan yabancı dil } \\
\text { olarak Türkçe }\end{array}$ & $\begin{array}{l}\text { T.C. } \\
\text { Başkonsolosluğu' nun } \\
\text { seçmeli/isteğe bağlı dersi }\end{array}$ & $\begin{array}{l}\text { T.C. } \\
\text { Başkonsolosluğ } u^{\prime} \text { nun } \\
\text { seçmeli/isteğe bağlı dersi }\end{array}$ & $\begin{array}{l}\text { T.C. } \\
\text { Başkonsolosluğu' nun } \\
\text { seçmeli/isteğe bağlı dersi }\end{array}$ \\
\hline Grundschule & $\begin{array}{l}\text { T.C. Başkonsolosluğu' nun } \\
\text { verilmektedir. Karnede sın }\end{array}$ & seçmeli/isteğe bağlı dersi & $\begin{array}{l}\text { siniftan 4. Sinıfa kadar } \\
\text { k değerlendirilmez. Derse }\end{array}$ \\
\hline
\end{tabular}

\footnotetext{
${ }^{12}$ Eğitim Ataşeliğinin 14.07.2015 tarihli yazısına cevaben bu ücretin, normalde derslik başına 8.00 Avro/Saat + KDV olduğu, \% 75'lik indirim ile 2.00 Avro+KDV olarak hesaplanacağı, aslında bu tutarın genel gideri karşılamamakla birlikte belediyenin anadili derslerine verdiği desteğin göstergesi olarak görülmesi gerektiği belirtilmiştir.

${ }^{13}$ Eyalet Eğitim ve Kültür, Bilim ve Sanat Bakanlı̆̆ı tarafından Bakan Danışmanı Alexandra Brumann'ın 01.03.2018 tarih ve III.2-BS7400.9.1/15/1 sayılı genelgesi uyarınca
} 
katılım belgelendirilir. Dersin açılabilmesi için 12 velinin dilekçe vermesi gerekir.

Farklı okullardan gelen talepler de tek bir okulda ders açılması için yeterlidir.

Tablo 3: Bavyera Eyaletinde Okul Türlerine Göre Türkçe Dersi

Bavyera Eyaleti Eğitim, Kültür, Bilim ve Sanat Bakanlığı eyaletteki bütün ilk ve ortaokul müdürlüklerine, eyalet eğitim yöneticilerine gönderdiği bir genelge ile Türkçe ve Türk Kültürü Dersinin [Muttersprachlicher Ergänzungsunterricht] Bavyera okul sisteminde uygulanan müfredatlardan çıkarılmış olduğunu; derslerin Konsolosluklar tarafından okullarda öğleden sonra gerçekleştirilen kültürel çalışmalar olarak değerlendirildiğini, bu kararla birlikte konsolosluklarca organize edilecek bu derslerle ilgili başvuru dilekçelerinin dağıtılmasını, toplanmasını ve başkonsolosluklara gönderilmesini üstlendiklerini bildirmektedir. Genelgede velinin istemesi halinde, derslere devam eden öğrencinin karnesine "Türkçe ve Türk Kültürü Dersini aldığına" dair bilginin yazılacağı; dersin mali giderlerinin konsolosluk tarafından karşılanacağını; kullanılacak öğretim materyallerinin ve ders içeriğinin konsolosluklarca belirleneceğini, öğretmenlerin çekecekleri fotokopilerin hangi amaçla yapıldığının okul yönetimlerince değerlendirilmesi gerektiği bilgisi verilmektedir. Burada ayrıca Türkçe Anadili Dersinin ortaokul bitirme sınavında başarı ölçütü olarak değerlendirilmeyeceği, Türkçe ve Türk kültürü dersine devam eden öğrencilerin not ortalamasını yükseltmek istemeleri halinde, ortaokulu nitelikli bitirme belgesi için girilen performans sinavinda [Leistungsfeststellung zum Erwerb des qualifizierenden Abschluss der Mittelschule] Türkçe dersini seçebilecekleri bildirilmiştir. Bu bilgilere ilave olarak, derse devam eden öğrencilerin devlet güvencesindeki okul sigortası kapsaminda olmadıkları konusunda uyarılmaktadır.

Bakanlık ile yapılan bütün temaslar dostane bir ortamda, karşılıklı nezaket anlayışında devam etmekte Türkçe ve Türk Kültürü Dersi ile ilgili ücret alınmaması konusundaki taleplerimize, "Genel giderlerin talep edilmesi kararının Münih Belediyesinin kararı olduğu, bu konuda bürokratlar olarak bir şey yapamayacaklarını" belirtmektedirler.

Eğitim öğretim yılı bitmeden önce bakanlık bürokratları ilgili ülkelerin (Türkiye, Hırvatistan, Portekiz, Macaristan, İtalya, İspanya) Başkonsoloslukları ile işbirliği yaparak genel duyuruları yapmakta, okul yönetimleri de -bazı istisnalar dişında- başvuru dilekçelerini öğrencilere dağıtmaktadır. Bu dağıtım sürecinde kesintiler yaşanabilmektedir; bazı belediyeler okul binalarının harcamalarından sorumlu kurumlar [Sachaufwandsträger] olarak işletme giderleri talep etmeye devam etmektedir. Bu talepler de derslerin yer yer kesintiye uğramasına neden olmaktadır. Bu karara karşı yerel sivil toplum kuruluşları da kendi imkânları ile okullardan derslik kiralayıp kendi köken dilleriyle ilgili dersleri açmaya 
Mustafa ÇAKIR - Güney Bavyera'daki Türkçe Anadili Dersi ve Türkçe Öğretmenleriyle İlgili Paradigmatik Bir Değerlendirme

çalışmaktadır. Yunanlılar, Japonlar, Fransızlar ise kurdukları özel okullar üzerinden eğitim öğretim faaliyetine devam etmektedir. Bu okulların diploma denklikleri kendi okul sistemleri ve uluslararası diploma üzerinden işlem görmektedir. Bu okullar diploma denkliği kabul edilen [anerkannte Schule] okul olarak değil, eğitim öğretime izin verilen [genehmigte Schule] okul statüsünde faaliyet göstermektedir.

15-17 Ekim 2018 tarihleri arasında Berlin'de yapılan 21. KEUK (Türk Alman Karma Eğitim Uzmanları Konferansı) toplantısında Bavyera Eyaleti Eğitim Müsteşarı Dr. Ulrich Seiser, dönemin Eğitim ve Kültür Bakanı Bernd Sibler'in bu konuda Belediye'ye yazdığı bir yazıdan olumlu cevap alamadıklarını, talebin yeni oluşacak yönetim ${ }^{14}$ nezdinde tekrar edilmesi halinde belki sonuç alınabileceği belirtmiştir.

12 Kasım 2018 tarihinde oluşturulan eyalet hükümeti kabinesinde Eğitim ve Kültür Bakanı Prof. Dr. Michael Piazolo olurken, önceki eğitim bakanı Bernd Sibler Bilim ve Sanat Bakanı olmuştur. İçişleri Bakanlığı Uyum Sorumlusu Milletvekili Gudrun Brendel-Fischer görevlendirilmiş; yardımcılığına da Dr. Michaela Krell getirilmiştir. Münih’teki Türk STK Temsilcileri de gerek bakanlık ziyaretlerinde, gerekse STK toplantılarında konuyu gündemde tutmaya devam etmektedir. Alman makamları ile yapılan görüşmelerden Bavyera Türk toplumu adına bu konuda ileri çözüm üretilmesi ihtimali zayıf görülmektedir.

\section{Türkiye Açısından Süreç Analizi}

Almanya Federal Cumhuriyeti ile Türkiye arasındaki eğitim ve kültür alanındaki ilişkiler 8 Mayıs 1957 tarihinde iki ülke tarafından imzalanan Türkiye-Almanya Kültür Anlaşması ile başlamıştır. Anlaşmanın yürürlüğe girmesiyle birlikte iki ülke temsilcilerinden oluşan Türk-Alman Daimi Kültür Komisyonu kurulmuştur. Anılan bu komisyon iki ülke arasındaki eğitim ve kültür faaliyetleriyle ilgili kararlar alıp uygulamasını da gerçekleştirmiştir. Söz konusu komisyon genelde her iki yılda bir dönüşümlü olarak Türkiye ve Almanya'da toplanmaktadır. Komisyon en son 27 - 28 Kasım 2014 tarihinde Ankara'da toplanmıştır.

Kültür Anlaşmasına bağlı olarak 26 Mayıs 1986 tarihinde imzalanan Ek Anlaşma ise 8 Mayıs 1957 tarihli Kültür Anlaşmasının 18. Maddesinde özellikle belirtilen Türk

\footnotetext{
${ }^{14}$ Bavyera Eyaletinde yerel yönetim seçimleri 2020 yılında yapılacaktır.
} 
Mustafa ÇAKIR - Güney Bavyera' daki Türkçe Anadili Dersi ve Türkçe Öğretmenleriyle İlgili Paradigmatik Bir Değerlendirme

okullarında görev yapmak üzere Türkiye'ye gelen Alman öğretmenlerin statülerini belirlemektedir ${ }^{15}$.

Diğer yandan Türkiye'de Bakanlar Kurulu Kararı ile “Bakanlıklararası Ortak Kültür Komisyonu" kurulmuş; Almanya ve diğer Batı Avrupa ülkelerinde yaşayan Türk çocuklarının Türk dilini, Türk kültürünü geliştirmek, milli duygularını pekiştirmek, kişilik gelişimi ile bulundukları ülkeye uyumlarını sağlamalarının teminen, 1973 yılından itibaren Türkçe-Türk Kültürü dersleri vermek üzere Türkiye' den öğretmen atanmaya başlamıştır.

AFC'deki eyaletelerin farklı eğitim politikaları nedeniyle bazı eyaletler Milli Eğitim Bakanlığınca gönderilen öğretmenleri kabul ederken (Bavyera, Baden Württemberg, Berlin, Hamburg, Bremen, Aşağı Saksonya, Schleawig Hollstein, Berlin, Hessen) bazıları kendi eyaletlerindeki Türklerin arasından öğretmen yeterliliği olanları (bazen de ihtiyaca binaen lise mezunlarını) görevlendirmişlerdir.

1970'li yılların başında AFC'deki Türk öğrenci sayısındaki artış ve sorunların çoğalması sonucu Türk-Alman Daimi Kültür Komisyonu aldığı kararla; sadece AFC'de yaşayan Türk çocuklarının eğitim öğretim sorunlarının ele alınarak çözüme kavuşturulması amacıla bir "Türk-Alman Karma Eğitim Uzmanları Komisyonu" (KEUK) kurulmasını kararlaştırmış ve söz konusu anlaşmaya da bu konuda ek bir madde eklenmiştir.

1976 yılından itibaren Milli Eğitim Bakanlığı, Dışişleri ve Maliye Bakanlıkları ile işbirliği yaparak, 1977 yılında yurtdışı teşkilatını kurmuştur. Bu tarihten sonra göreve atanan Müşavir ve Ataşelerle Alman Eğitim yetkilileri arasında temaslar ve işbirliği sağlanmaya başlanmıştır. Yine aynı şekilde öğretmen ihtiyacı da tespit edilmiş ve Türk çocuklarının Türkçe-Türk Kültür Dersleri almasını teminen çok sayıda öğretmen görevlendirilmiştir.

Günümüzde Bavyera eyaletinde Kuzey (Nürnberg Başkonsolosluğu görev bölgesi) 24 öğretmen, 3 okutman ve Güney Bavyera (Münih Başkonsolosluğu görev bölgesi) 41 öğretmen 2 okutman Türkçe ve Türk Kültürü Dersi öğretmeni olarak görev yapmaktadır.

\footnotetext{
${ }^{15}$ Kültür Alanında İkili Anlaşmalar. 29.12.2018 tarihinde https://tuerkei.diplo.de/tr-de/themen/kultur/-/1797646 adresinden erişilmiştir.
} 
Mustafa ÇAKIR - Güney Bavyera'daki Türkçe Anadili Dersi ve Türkçe Öğretmenleriyle İlgili Paradigmatik Bir Değerlendirme

Anılan Türk-Alman Karma Eğitim Uzmanları Komisyonu (KEUK) da önceleri her yıl dönüşümlü olarak Türkiye ve Almanya'da bir araya gelerek Türk çocuklarının sorunlarına çözüm aramış ve alınacak tedbirleri tespit edip, uygulamaya koymuş, uygulamada meydana gelen aksamaları da temsilciliklerimizle işbirliği içersinde gidermeye çalışmıştır. Söz konusu komisyon son toplantılarını iki yılda bir yapmaya başlamış olup, son toplantı 15-17 Ekim 2018 tarihlerinde Berlin'de gerçekleştirilmiştir.

Münih Başkonsolosluğu Eğitim Ataşeliği görev bölgesinde Bakanlığımız öğretmenleri tarafından verilmekte olan Türkçe ve Türk Kültürü (TTK) derslerine katılan öğrenci sayısı 15 Aralık 2018 tarihi itibari ile 232 okul ve dört ayrı Sivil Toplum Kuruluşlarında olmak üzere toplam 2614'tür. 2018/2019 eğitim öğretim yılında çalışmakta olan Türkçe ve Türk Kültürü Dersi öğretmeni sayısı toplam 41 kişi olup, öğretmen başına düşen öğrenci sayısı ise 65 , okul sayısı 5,6' dır.

\section{Problem}

Ülkelerin gelişmesinde görev alan kurumların başarıları, bünyesinde çalıştırdıkları bireyleri geliştirebilmeleri ve değişimlere ayak uydurabilecek isteği yaratabilmelerine bağlıdır. Bireylerin gelişim ve değişim süreci ise hizmet öncesi eğitim kadar önemli olan hizmet içi eğitim ile de çözülebilecek bir sorundur.

Almanya Federal Cumhuriyeti ile yapılan ikili anlaşmalara ve ülkelerimiz arasındaki çok yönlü işbirliğine rağmen ülkede yaşayan zorunlu eğitim çağındaki Türkiye kökenli çocuklara verilen Türkçe derslerine katılımın arzu edilen düzeyde olmadığı görülmekte; öğrenci sayıları artmasına karşın, Türkçe ve Türk kültürü dersine devam eden öğrenci sayıları azalmaktadır.

Türkiye Cumhuriyeti Münih Başkonsolosluğu görev bölgesindeki Türkiye kökenli nüfus sayısının büyüklüğü, yerleşim yerlerinin/ okulların dağınıklığı, derslerin zorunlu ders saatleri dışında verilmesi, bazı belediyelerin ders yapılacak okullardan işletme giderleri ve derse devam edecek çocuklara sigorta yaptırılması şartını ileri sürmesi, derslere devam etmeyi arzu eden öğrencilerin zaman sınırlılığı, vatandaşların beklentilerindeki farklılık (Türkçe dersiyle ilgili olarak oluşturulan içerik algısının toplumsal katmanlara ve demografik faktörlere göre farklı olması), öğretmenlerin bireysel farklılığı ve yurt dışı göreve 
Mustafa ÇAKIR - Güney Bavyera'daki Türkçe Anadili Dersi ve Türkçe Öğretmenleriyle İlgili Paradigmatik Bir Değerlendirme

ilişkin beklentilerinin karşılanamayışı, nitelikli öğretmen sınırlılı̆̆ı gibi nedenler Türkçe eğitim öğretimini olumsuz etkilemektedir.

\section{Amaç}

Çalışmanın amacı, Bavyera Eyaletindeki Türkçe ve Türk Kültürü Dersi ile ilgili olarak kamuoyunca bilinmesi gereken bilgileri sistematik şekilde gözlem ve deneye bağlı olarak bilimsel bilgiye dönüştürmektir. Bu amaçla kamuoyunda bilinen bilgilerin doğruluk durumunu ortaya koyma ve Güney Bavyera Eyaletinde bulunan öğretmenlerin demografik özellikleri, mesleki deneyimleri gibi durumları saptamaya yöneliktir.

Bu kapsamda yapılan çalışmanın alt amaçları şu şekilde belirlenmiştir:

1. Türkçe ve Türk Kültürü Dersinin verilmesiyle ilgili mevzuata dayalı çalışmalar ve mevcut uygulama nasıldır?

2. Öğretmenlerin demografik özelliklerinin hizmetin sürdürülmesinde farkındalık yaratan bir durum söz konusu mudur?

3. Öğretmenlerin branşlarına göre dağılımları nasıldır?

4. Öğretmenlerinin hizmet yılı değişkenine dağılımları nasıldır?

5. Öğretmenlerinin Yurtdışı Görev Süresi değişkenine göre dağılımları nasıldır?

6. Öğretmenlerinin eğitim durumu değişkenine dağılımları nasıldır?

7. Öğretmenlerinin yabancı dil bilgisi değişkenine göre dağılımı dağılımları nasıldır?

8. ̈̈̆gretmenlerinin 2. yabancı dil (İngilizce) dil değişkenine göre dağılımları nasıldır?

\section{Araştırmanın Önemi}

Türkiye Cumhuriyeti vatandaşlarının ihtiyaçlarının karşılanması, eğitim sorunlarının mütekabiliyet esasına göre çözülmesi ve öngörülen eğitim hedeflerine ulaşılması için Almanya Federal Cumhuriyeti ile her kademede etkili ve sonuç odaklı bir işbirliği politikası izlemektedir. Almanya'da verilen eğitim hizmetlerinin niteliğinin geliştirilebilmesi için analiz basamaklarına göre öğretmen kaynağının niteliğinin belirlenmesi, işgücünün verimlilik analizinin yapılması, sevk ve idaresi, eğitim öğretim etkinliklerinin planlanması ve uygulaması açısından büyük önem taşımaktadır. Bu özellikler, öğretmenlerin her hangi bir durum ya da olay karşısındaki çaba, ilgi ve başarılarının ne düzeyde olacağı konusunda kestirimler yapılmasına yardımcı olacaktır. Bu bağlamda öğretmenlerin demografik özellikleri, deneyimleri ve diğer konular, Türkçe ve Türk Kültürü dersi ile öğretmen yeterlilikleri arasındaki ilişkiyi de bir ölçüde ortaya koyabilir. 
Mustafa ÇAKIR - Güney Bavyera'daki Türkçe Anadili Dersi ve Türkçe Öğretmenleriyle İlgili Paradigmatik Bir Değerlendirme

1. Türkçe ve Türk Kültürü dersinden istendik verimin alınabilmesi için Türkiye'den yapılan öğretmen seçiminde ve yurt dışı görevlendirmelerde yararlı olabilir.

2. Öğretmenlerin çaba, ilgi ve başarılarını tahmin etmeye yönelik olarak ilerleyen zaman dilimi içinde yapılacak yeni araştırmalar için fikir oluşturabilir.

\section{Varsayımlar}

$\mathrm{Bu}$ çalışma ile gözlem ve deneylere dayalı, ilişkiler sistematiğine ilişkin olarak önyargılardan uzak, kişisel kanaatlerin üzerinde ve duyguların etki alanı dişında bilimsel bilgiye dayalı veriler oluşturulacaktır. Bunun dışında aşağıdaki varsayıma dayanmaktadır:

1. Öğretmenlere gönderilen veri toplama aracı özlük dosyalarındaki bilgilerden bir kısmı ile örtüştüğünden elde edilen verilerin geçerli ve güvenilir olacağı;

2. Elde edilecek veriler ile bir sonraki bilgiye ulaşmak mümkün olacağ1 varsayılmıştır.

\section{Sinırlılıklar}

Çalışmada olması gerekenlerden ziyade, var olan üzerinde yoğunlaşılmıştır. Bu yüzden olgusaldır. Verilen bilgiler de inandırma olmayıp, göç tarihi süresince yaşanan belli olaylar arasında ilişki kurmak suretiyle sonuçlara varılmaya çalışılmıştır. Dolayısı ile aşağıdaki sınırlılıkların, araştırmanın sonuçlarını ve bu sonuçların sebep-sonuç ilişkisiyle genellenerek genel kavramlara yükseltilerek bilimsel bilgiye dönüştürüleceği öngörülmüştür.

1. Çalışma kayıtlı arşivde yer alan bilgi, belgeye dayalı "sözlü tarih araştırması" (kaynak arama, sınıflandırma, çözümleme, eleştiri ve verilerin analizi) tekniği ile de desteklenmiştir.

2. Anket üzerinden toplanan veriler, Güney Bavyera'da görev yapan 41 öğretmenden oluşan örneklem grubu ile sınırlıdır.

3. Çalışma, öğretmenlerin demografik özellikleri ve yukarıda sayılan alanlardan elde edilen verilerle sinırlıdır.

\section{YÖNTEM}


Mustafa ÇAKIR - Güney Bavyera' daki Türkçe Anadili Dersi ve Türkçe Öğretmenleriyle İlgili Paradigmatik Bir Değerlendirme

Aşağıda çalışmanın modeli, bağlamı, çalışma kümesi, verilerin toplanması, çözümü ve yorumlaması ile süre ve imkânlar konusundaki bilgiler verilmiştir.

\section{Araştırma Modeli}

Araştırma, durum saptamaya yönelik betimsel bir çalışma olup (Karasar 2013; Friedrichs 1980), Türkçe ve Türk Kültürü Dersinin açıldıktan sonra göç tarihi içindeki seyri arşivde yer alan bilgi, belgeye dayalı "sözlü tarih araştırması" tekniğinden (kaynak arama, sinıflandırma, çözümleme, eleştiri ve verilerin analizi) yararlanarak dersin güncel uygulamadaki durumu ve bu dersi veren öğretmenlerin demografik özellikleri, mesleki deneyimleriyle ilgili ilişkileri anket kullanılarak kendiliğinden var olan kümeler üzerinde çalışılarak istatistiksel sonuçlar çıkarılmaya çalışılmıştır (Karasar 2013, 110). Araştırmada evren ve örneklemin aynı kümeden olması kontrol grubu kullanılmasına imkân vermemiştir.

\section{Araştırma Bağlamı}

Araştırma Milli Eğitim Bakanlığı tarafından Türkiye Cumhuriyeti Münih Başkonsolosluğu Eğitim Ataşeliği görev bölgesi olan Güney Bavyera illerinde (Oberbayern, Niederbayern und Schwaben) görev yapan 41 Türkçe ve Türk Kültürü (TTK) dersi öğretmeni üzerinde yapılmıştır. Amacı, Bavyera Eyaletindeki derslerin genel durumunu ve Ataşeliğimiz görev bölgesindeki öğretmenlerin demografik özelliklerini tespit etmek ve elde edilen verilerden geleceğe yönelik çıkarımlar sağlamaktır.

\section{Çalışma Kümesi}

Münih Başkonsolosluğu Eğitim Ataşeliği görev bölgesinde 2018/2019 eğitim öğretim yılında çalışmakta olan toplam 41 Türkçe ve Türk Kültürü Dersi öğretmeni vardır. Bu kapsamda yapılan araştırmanın çalışma kümesi görev bölgemizdeki öğretmenlerden oluşturmaktadır. Güney Bavyeradaki belli başlı şehirler; Münih, Augsburg, Ingolstadt, Landshut, Kempten, Rosenheim, Freising, Straubing, Neu-Ulm ve Passau olmak üzere on adettir.

\section{Verilerin Toplanması, Çözümü ve Raporlaştırılması}

Verilerin toplanabilmesi için Ataşelik bünyesinde demografik bilgileri de içeren ve toplam sekiz açık uçlu sorudan oluşan "Öğretmen Akademik Gelişim Takip Formu” oluşturulmuş; 2018-2019 eğitim öğretim yılı başında bütün öğretmenlere gönderilmiştir. 41 
Mustafa ÇAKIR - Güney Bavyera'daki Türkçe Anadili Dersi ve Türkçe Öğretmenleriyle İlgili Paradigmatik Bir Değerlendirme

öğretmenin tamamı kendilerine verilen süre içinde formu doldurmuştur. Doldurulan formlar tek tek incelenmiş; eksik ya da hatalı doldurulan formlar güncellenmiştir. Verilerin ve cevapların anonim olması için her bir form numaralandırılmış; bu işlemlerden sonra bilgisayara aktarılmış; nitel verilerin çözümlenmesi için içerik analizi yapılmış ve sonrasında ortaya çıkan nicel verilerin analizi için de istatistiksel teknikler, sayısal dağılımlar için frekans ve yüzdelerden yararlanılmıştır. Kimi veriler örneklemin genel özellikleri itibarı ile tek yönlü tablolara dönüştürülmüş, kimi veriler de grafikler şeklinde sunulmuştur. Araştırma ile elde edilen veriler, bilgisayar ortamında Microsoft Office programları yardımıyla bilim dünyasında kabul göre APA VI formatında raporlaştırılmıştır.

\section{BULGULAR VE YORUM}

Gelişen ve kendini yenileyen eğitim ortamlarında eğitim örgütlerinin yeniden tasarlanması ve sürece ayak uydurması beklenmektedir. Bu süreçte örgüt çalışanlarının da ihtiyaca göre seçilmesi, istihdam edilmesi, iş tanımlarının yeniden belirlenmesi ve buna göre performans analizlerinin yapılması gerekmektedir. İş analizi ve tanıtımı insan kaynakları yönetiminin başta gelen görevleri arasında olup, gerekli altyapının oluşturulabilmesi için işgören kadar işverenin de işin yapısını bilmesi gerekir. İşin yapısını yakından incelemedikçe ve tanımadıkça çalışanı incelemek ve tanımak ya da iş ile çalışan arasındaki ilişkiyi tespit etmek zor olacaktır (Bkz.: Çelikten 2005, 128). Yurt dışına çalışmak üzere gönderilen öğretmenler "Benden ne iş yapmamı bekliyorsunuz?" sorusuna karşılık olarak iş konusunda iletişim ve anlayış geliştirilemezse, iletişim engellendiği gibi, sürece de olumsuz yansımaktadır. Öğretmenlerin cinsiyet dağılımına göre edilen bulgular ve yorumu aşağıda verilmiştir ${ }^{16}$.

\section{TTK Öğretmenlerinin Cinsiyet Değişkenine Göre Dağılımı}

\footnotetext{
16 Sayısal veriler ve grafiklerin hazırlanmasından dolayı TC Münih Başkonsolosluğu Eğitim Ataşeliği merkez koordinatör öğretmeni Umut ÇALTAK'a teşekkür ederim.
} 


\section{Cinsiyet Dağılımı}

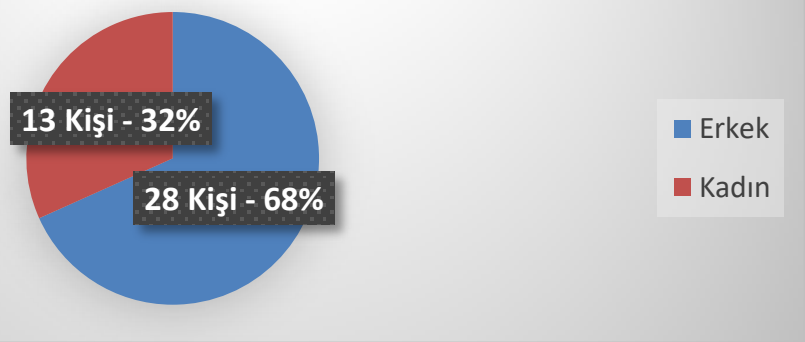

Grafik 1: TTK Öğretmenlerinin cinsiyet değişkenine göre dağılımı

Grafik 1'e göre Güney Bavyera görev bölgesinde çalışmakta olan öğretmenlerin \% 68 'i erkeklerden oluşmaktadır. Bu oran 28 sayısına denk gelmektedir. Buna karşılık \%32 oranına karşılık gelen kadın öğretmen sayısı ise 13'tür. Güney Bavyera'da görevli öğretmenlerin cinsiyet dağılımında erkek ağırlığının bulunduğu görülmektedir.

\section{Cinsiyet Dağılımı}

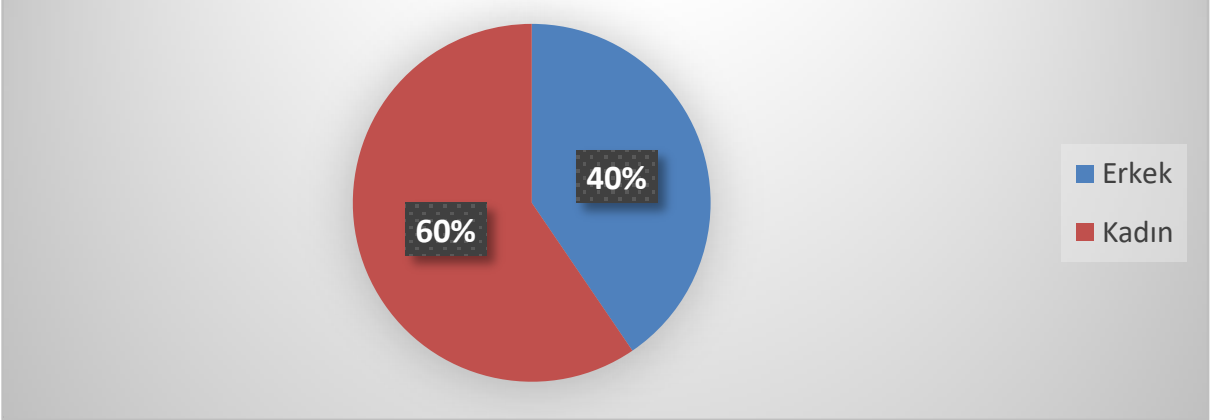

Grafik 2. MEB Bağlı öğretmenlerin cinsiyet değişkenine göre dağılımı1 ${ }^{17}$

Millî Eğitim Bakanlığına bağlı resmi ve özel ilk ve ortaöğretim kurumlarında görev yapan öğretmenlerin cinsiyet dağılımı ile kıyaslandığında, Türkiye'deki yansımanın tersi bir durum görülmektedir. Kadın öğretmenlerin öğrenci ortalaması 72,5 iken erkek öğretmenlerde bu sayı $62^{\prime}$ dir. Erkek öğretmenler ortalama 5,5 okulda çalışırken, kadın öğretmenler ise ortalama 6,2' dir.

Grafik 1 ve 2 incelendiğinde, çıkan sonucunun iyi değerlendirilmesi ve TTK derslerinde istenen başarının yakalanması için kadın etkisinin olup olmadığı konusunun

\footnotetext{
${ }^{17}$ Millî Eğitim İstatistikleri 2017-2018. (2018). Milli Eğitim Bakanlığı, Ankara.
} 
Mustafa ÇAKIR - Güney Bavyera'daki Türkçe Anadili Dersi ve Türkçe Öğretmenleriyle İlgili Paradigmatik Bir Değerlendirme

araştırılması; kadın öğretmenlerin yurtdışında çalışmayı tercih etmesi halinde, cinsiyet durumunun eğitime yansımasının nasıl olacağı araştırmacılar tarafından değerlendirilecek yeni alanlar olarak görülmektedir.

\section{TTK Öğretmenlerinin Medeni Halleri}

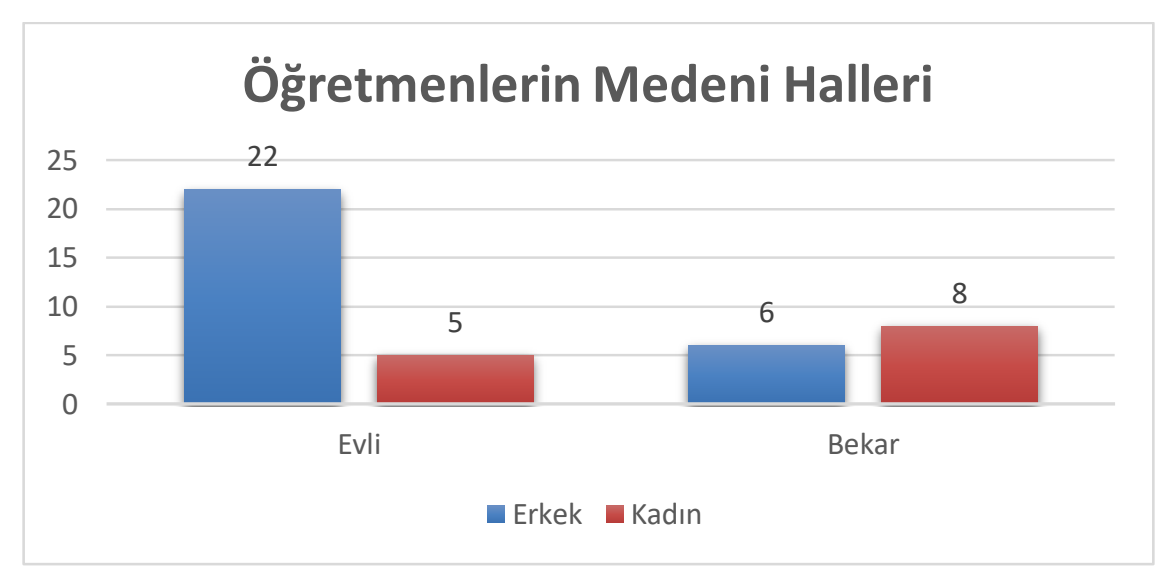

Grafik 3. TTK Öğretmenlerinin medeni halleri

Grafik 3'ten anlaşılacağı üzere öğretmenlerin medeni halleri dikkat çekmektedir. Buna göre,

a. Erkek öğretmenlerin büyük çoğunluğu evli iken, kadın öğretmenlerin çoğunluğu bekârdır.

b. $\quad$ Evli 3 kadın öğretmenin 2'sinin eşleri yine TTK Öğretmenliği yaparken, bir öğretmenimizin eşi Bavyera Eğitim Bakanlığına bağlı İslam Kültür Dersi öğretmenliği yapmaktadir.

c. $\quad 22$ evli erkek öğretmenin 8'si aileleri ile yaşamaktadır.

Sayıların sunduğu tablo şu şekilde değerlendirilebilir. Türk toplumsal yapısı evli kadınların eşlerini ve kurulu düzenlerini bırakarak yabancı bir ülkede çalışmasına olumlu bakmamaktadır. Aile ile gelecek öğretmenler için verilen 1.975,- Avro yurtdışı görev ödeneği yurt dışında geçim temini için yetersiz görülmekte, evli kadın öğretmenlerin tercihini olumsuz etkileyebilmektedir. Alman öğretmenler ile yapılan karşılaştırma, düşük olduğu görülen bu miktarın sadece öğretmenin temel ihtiyaçlarına yeteceği, ailesi ile gelen bir öğretmenin asgari standartların altında bir yaşam sürmesine neden olacağı var sayılmaktadır. Ancak burada öğretmenlerin Türkiye'deki maaşları hesaba dâhil edilmemektedir. Yurt dışı görev ödeneğini maaş olarak gören anlayış, Alman tarafında da mevcut olup, öğretmenlerin vize işlemlerinde "yetersiz gelir" beyanı olarak değerlendirilebilmektedir. Mülakat sınavını geçen evli kadın öğretmenlerin, öğretmen olan 
Mustafa ÇAKIR - Güney Bavyera'daki Türkçe Anadili Dersi ve Türkçe Öğretmenleriyle İlgili Paradigmatik Bir Değerlendirme

eşleri ihtiyaca binaen aynı görev bölgesinde değerlendirilmesi, kadın öğretmenlerin yurtdışı görevine ilgilerini artırabilir. Böylece aile birliği sağlanan öğretmenlerin daha verimli çalışabileceği öngörülmektedir.

TTK Öğretmenlerinin Hizmet Yı1ı Değişkenine Göre Dağılımı

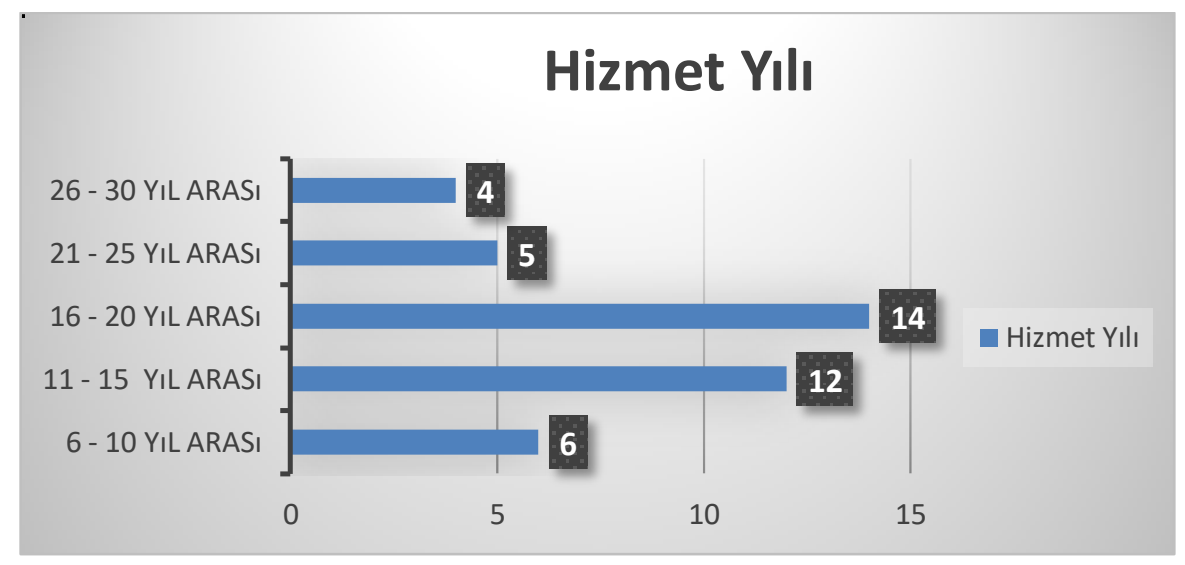

Grafik 4. TTK öğretmenlerinin hizmet yılı değişkenine göre dağılımı

Güney Bavyera'da çalışan öğretmenlerin hizmet yılı ortalaması 16,7'dir. Yurtdışı göreve başvuru ancak 5. meslek yılından sonra mümkün olabilmektedir. Bu açıdan bu ortalama kariyerinin başında olan ve evlilik veya başka sebeplerle hayatını yerleşik bir düzene oturtan öğretmenlerin yurtdışı görevi pek tercih etmedikleri burada bir kere daha teyit edilmektedir. Grafikteki yığılmanın 11 ve 20 yıl arasında olduğu görülmektedir. $\mathrm{Bu}$ yığılma Güney Bavyera'da çalışan öğretmenlerin yeterince deneyimli olduklarını göstermektedir. Ancak bu deneyim bir noktadan sonra yurt dışında öğretmenlik yapmaktan duyulan manevi doyumun duygusal tükenme ve beraberinde mesleki duyarsızlaşmayı getirdiği gözlenmektedir.

2018/2019 eğitim öğretim yılı sonunda öğretmenlerin \% 50'sinin Almanya'daki beş yıllık görev süresinin sona erecek olması, grafikteki verilerin önemli ölçüde değişmesini sağlayacaktır. Dolayısı ile öğretmenlerin yurt dışındaki görev süreleri ile mesleki doyum ve tükenmişlik düzeyleri arasında anlamlı ölçüde bir farklılığın olup olmadığı ayrı bir araştırma konusu olabilir (Bu konuda ayrıca bkz.: Cemaloğlu, Erdemoğlu Şahin 2007).

\section{TTK Öğretmenlerinin Branş Değişkenine Göre Dağılımı}




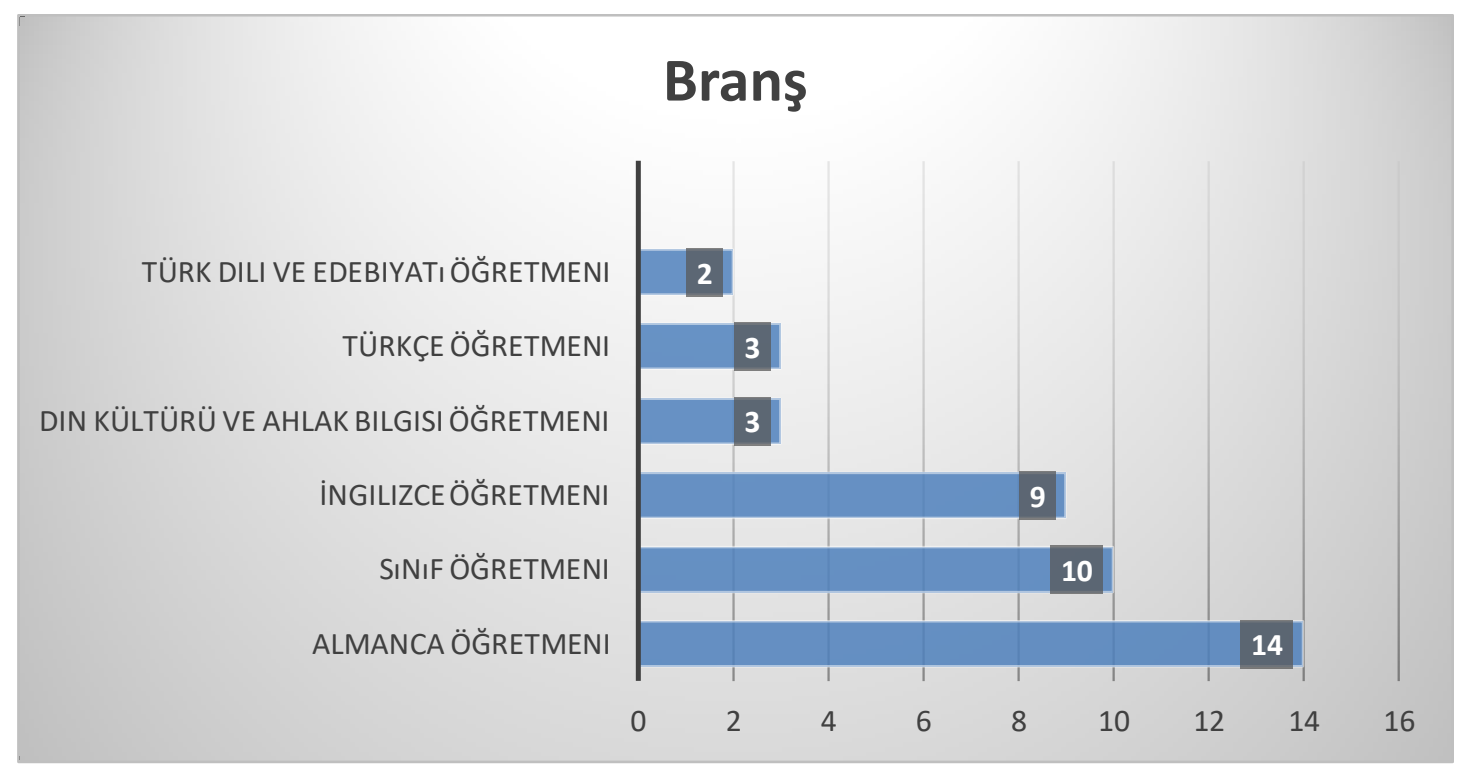

Grafik 5. TTK öğretmenlerinin branş değişkenine göre dağılımı

Branş dağılımına bakıldığında Almanca Öğretmenliği birinci sırada olduğu görülmektedir. Güney Bavyera'da toplam 14 Almanca öğretmeni kökenli TTK öğretmenli bulunmaktadır. Bunun altında yatan neden, Almanya'nın gönderilen öğretmenlerin Almanca dil bilgisine sahip olmasın talep etmesidir. Almanca bilmiyorsa, İngilizce dil bilgisine sahip olunması isteğinin sonucu olarak da İngilizce dil puanı ile başvuruda bulunan İngilizce öğretmenliği ve sınıf öğretmenliği çıkışlı olan iki yaygın alan olarak öne çıkmaktadır. Anadili tamamlama ve geliştirme amacı ile gönderilen öğretmenler arasında Türkçe öğretmeni sayısının azlığı, mevcut öğretmenlerin de yabancı dil yetersizliği dikkat çekicidir. Bölgemizde 3 tane de Din Kültürü ve Ahlak Bilgisi öğretmenliği çıkışlı TTK öğretmeni görevlendirilmiştir. Yerel makamlara DKAB öğretmeni görevlendirilmesiyle ilgili açıklama yapılması konusunda yetersiz kalınmaktadır. İhtiyaç analizine bağlı olarak yapılan görevlendirmelerde, “her örgütün yapısına uygun tek bir seçenek yoktur ve en iyi duruma göre değişir" anlayışının hâkim olduğu ve stratejik yönetimde durumsallık yaklaşımı ile bütünleştirildiği görülmektedir (Çelik 1993, 28'den aktaran Tümer 1993).

Öğretmenler bu yaklaşıma bağlı olarak, yeni TTK öğretmenliği görevlerini üstlenip yerine getirirken, bir takım hakların sahibi oluyorlar ve Almanca öğrenme gibi bir takım sorumlulukları da yerine getirme yükümlülüğünü peşinen kabul ediyorlar.

\section{TTK Öğretmenlerinin Yurtdışı Görev Süresi Değişkenine Göre Dağılımı}


Mustafa ÇAKIR - Güney Bavyera'daki Türkçe Anadili Dersi ve Türkçe Öğretmenleriyle İlgili Paradigmatik Bir Değerlendirme

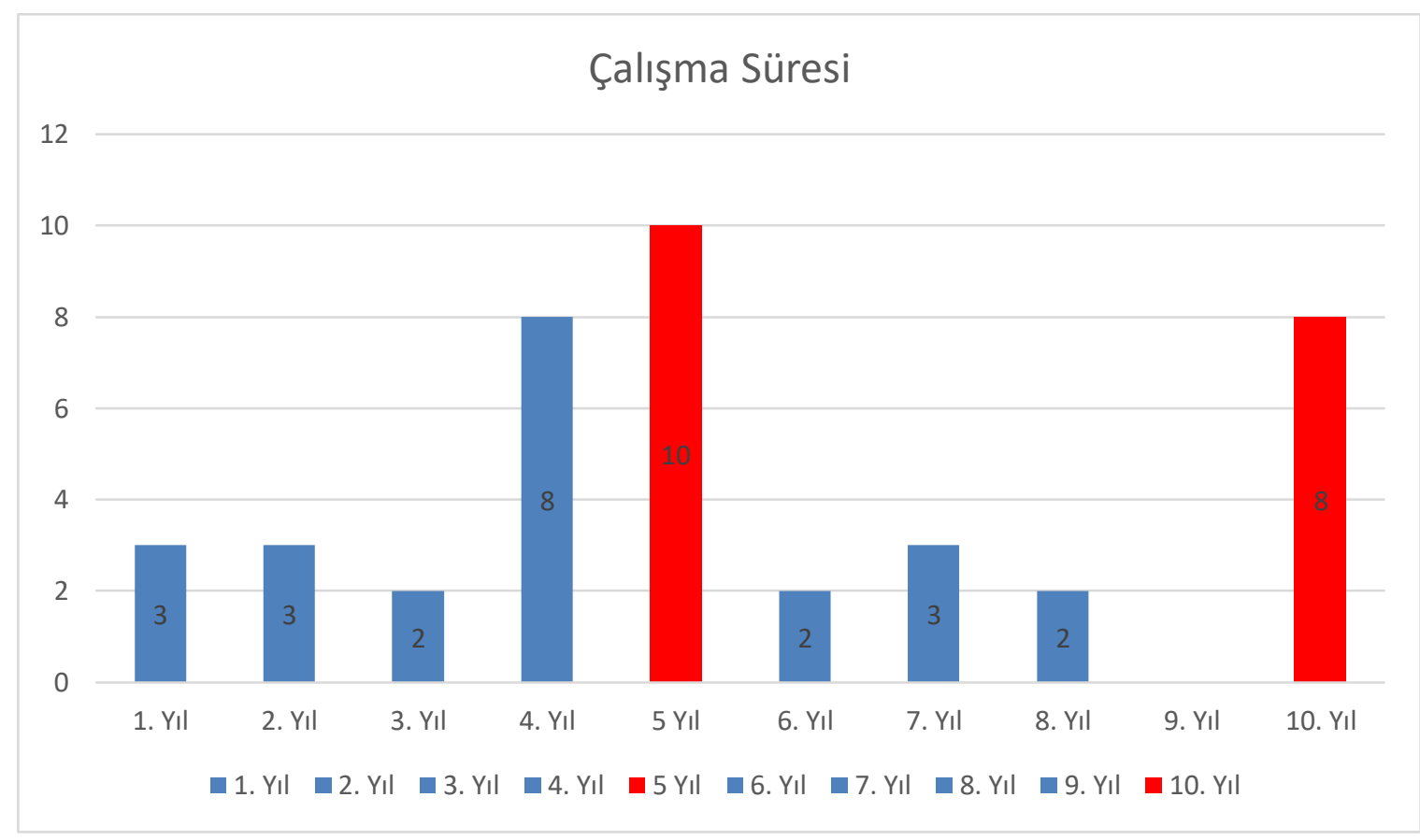

Grafik 6. TTK öğretmenlerinin Yurtdışı Görev Süresi değişkenine göre dağılımı

Güney Bavyera' da görev yapan 14 TTK öğretmeni dışında kalan 27 öğretmen ilk beş yıllık görev sürelerini çalışmaktadırlar. Kırmızı ile gösterilen öğretmenler ise 2018-2019 eğitim öğretim yılı sonunda yurt dışı görev sürelerini tamamlayarak Türkiye'ye dönecektir. $\mathrm{Bu}$ öğretmenlerin yerine yeni görevlendirme yapılamaması halinde, bölgemizde büyük bir öğretmen açığı ortaya çıkacaktır. Öte yandan yıllara göre dağılımın eşit olmaması ve aynı yıl içerisinde çok sayıda yeni öğretmenin Türkiye'ye dönmesi, bunların yerine yenilerinin göreve başlaması, beraberinde yeni sorunları getirmektedir. 2014 ve 2015 yıllarında ilk kez yurtdışı görevine gelen 18 öğretmenden sadece biri Almanca öğretmenidir. Bunun dişında kalan öğretmenlerin hepsi başka branşlardan ve sadece İngilizce bilerek Almanya'ya gelmiştir. Ataşeliğimiz görev bölgesinde yaşanan sorunların çoğunluğu bu değişimden ve öğretmenlerin ilk yıllarını dil zorlukları nedeni ile uyum süreci şeklinde geçirmelerinden kaynaklandığı düşünülmektedir.

\section{TTK Öğretmenlerinin Eğitim Durumu Değişkenine Göre Dağılımı}


Mustafa ÇAKIR - Güney Bavyera'daki Türkçe Anadili Dersi ve Türkçe Öğretmenleriyle İlgili Paradigmatik Bir Değerlendirme

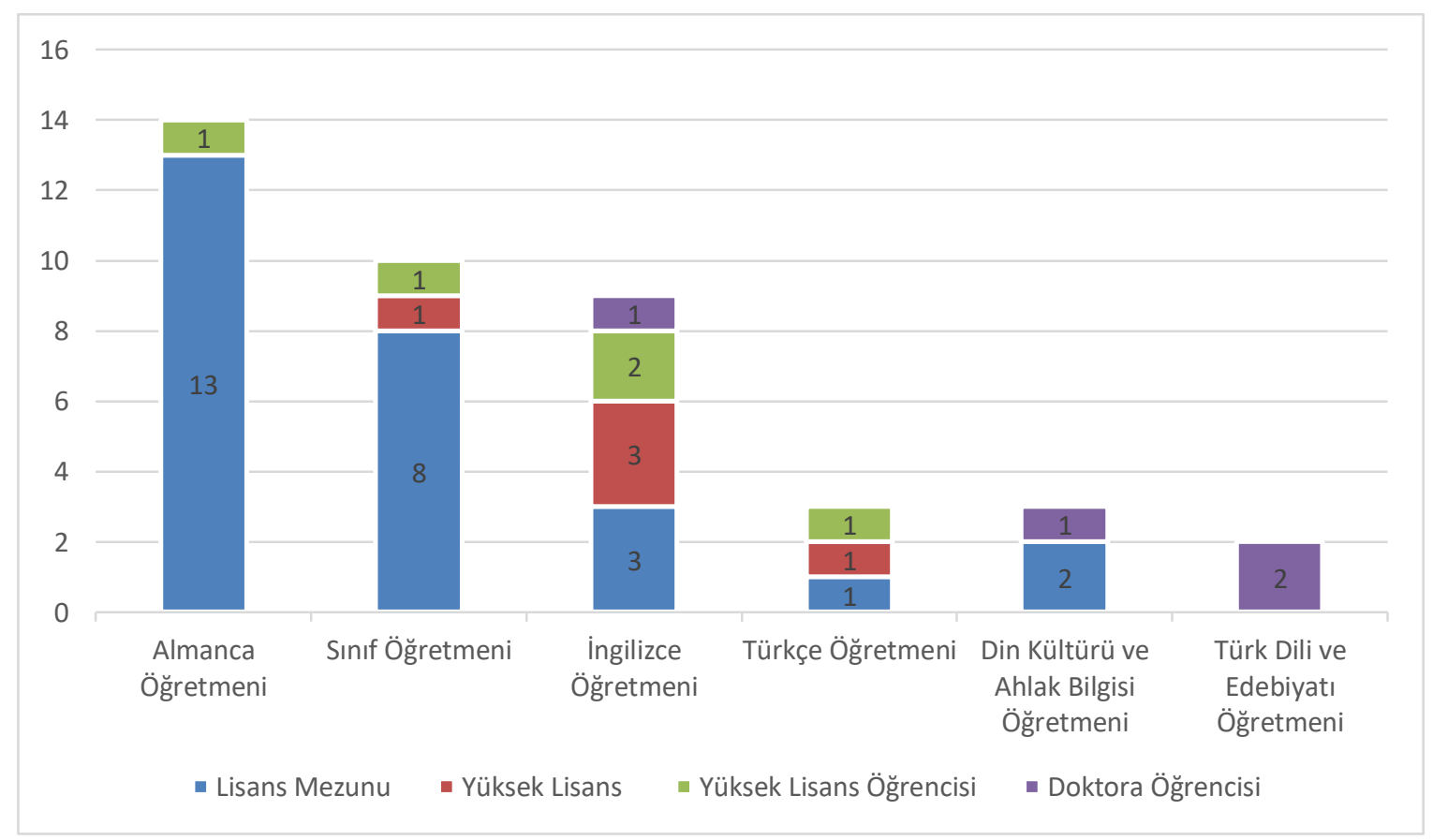

Grafik 7. TTK öğretmenlerinin eğitim değişkenine göre dağılımı

TTK Öğretmenlerinin \% 66'sı lisans mezunudur. Bölgemizde çalışan 14 Almanca öğretmeninden 13'ü sadece lisans mezunudur. Bu öğretmenlerden 10'u ikinci görevlerini çalışmalarına ve "teoride" dil sorunu olmamalarına rağmen ileri eğitimin neredeyse ücretsiz olduğu ve kabul almanın kolay olduğu Alman üniversitelerinde lisansüstü eğitimi gereksiz görmüşlerdir. Bu durum sınıf öğretmenleri arasında da geçerlidir. 2. görevini çalışmakta olan ve Almanca bilmekte olan 4 sınıf öğretmeni herhangi bir yüksek eğitime gerek duymamıştır. Toplamda 2. görevini çalışmakta olan 15 öğretmenden sadece 1 öğretmen uzaktan eğitim yoluyla Türkiye'de yüksek lisans yapmıştır. Türkiye Cumhuriyeti'nin yurt dışına öğretmen gönderme amaçlarından biri de öğretmenlerin mesleki ve dil bilgilerini geliştirmeleri ve yurda dönüşte bu kazanımlarını diğer meslektaşları ile paylaşılmasıdır. 10 sınıf öğretmeninden sadece 1 tanesi yüksek lisansını tamamlamış, 1 tanesi de halen yüksek lisansına devam etmektedir. Toplam 14 olan İngilizce, Türkçe ve Türk Dili ve Edebiyatı öğretmeninin 10'u lisansüstü eğitimi yapmış ya da yapmaktadır. Branşlar arasındaki lisans sonrası eğitime duyulan ilgi farklılı̆̆ dikkat çekici ve araştırmaya değer bir konudur.

\section{TTK Öğretmenlerinin Yabancı Dil Bilgisi Değişkenine Göre Dağılımı}

Bu çizelgede TTK öğretmenlerinin Kamu Personeli Yabancı Dil Bilgisi Seviye Tespit Sınavı (KPDS), Üniversitelerarası Kurul Yabancı Dil Sınavı (ÜDS) ve Yabancı Dil Bilgisi Seviye Tespit Sınavında aldıkları (YDS) sonuçların Avrupa Ortak Dil Çerçevesi Seviyeleri ile ÖSYM'ce kabul edilen karşılıkları kullanılmıştır. Ayrıca öğretmenlerin Almanya'da kabul geçerliliği bulunan sınavlarda almış oldukları dereceler de işlenmiştir. Ülkemizde yapılan dil 
Mustafa ÇAKIR - Güney Bavyera'daki Türkçe Anadili Dersi ve Türkçe Öğretmenleriyle İlgili Paradigmatik Bir Değerlendirme

sınavlarının iletişim yeteneklerinden ölçmeden ziyade dil bilgisi ağırlıklı olmasından dolayı, özellikle Almanca Öğretmenlerinin iletişim becerilerinin tabloda işlenen sonuçlardan daha iyi bir düzeyde olduğu gözlenmektedir. Fakat şunu da belirtmeliyiz ki, bu değerlendirme sistemine göre dil öğretmeni yetiştiren eğitim fakültelerinden mezun olan bazı Almanca öğretmenlerinin Almanca iletişim becerilerinde yetersiz olduğuna dair Alman müdürlerinden ve velilerden geri dönütler alınmaktadır. Çalışmamızda bu iki hususa yönelik herhangi bir bulgu ortaya koymadığımız gibi, bu iki husus çalışmamızın sinırlıklarıdır.

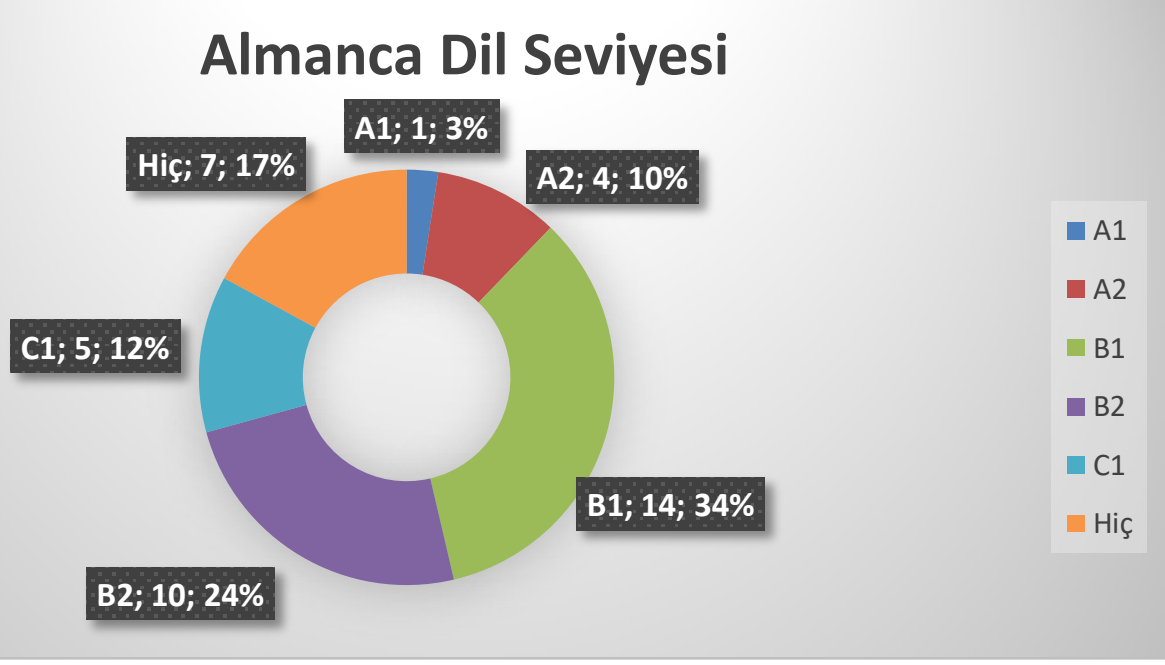

Grafik 8. TTK öğretmenlerinin yabancı dil bilgisi değişkenine göre dağılımı

$\mathrm{Bu}$ çizelgede en dikkat çekici olan 7 öğretmenin görev yaptı̆̆ ülkenin diline dair herhangi bir dil bilgisine sahip olmamasıdır. Bu 7 öğretmenin 1 tanesi 3. yılını, 3 tanesi 4. yıllarını ve diğer geriye kalan 3 tanesi de 5. yıllarını çalışmaktadırlar. Bakanlığının gönderdiği öğretmenlerin ilk yılın sonunda A2, 2. yılın sonunda da B1alamayan öğretmenin görev süresini uzatmamasına yönelik bir yasal düzenleme oldukça etkili bir motivasyon kaynağı olacaktır.

Güney Bavyera'da görev yapmakta olan 3, 4 ve 5. yılını çalışmakta olan 10 İngilizce öğretmeninden sadece ikisi bu süre içerisinde Almanca C1 seviyesine ulaşabilmiştir. Geriye kalan öğretmenlerden biri B1, biri A2 ve diğer biri de A1 Almanca seviyesine ulaşabilmiştir.

Sınıf öğretmenlerinde ise durum farklıdır. 10 sınıf öğretmeninden yedisi Almancadan sınava girip, mülakatı geçmiştir. Geriye kalan üç öğretmen de görev süreleri içinde belli bir Almanca dil düzeyine ulaşmıştır. Sayıları 5 olan Türkçe ile Türk Dili ve Edebiyatı 
Mustafa ÇAKIR - Güney Bavyera'daki Türkçe Anadili Dersi ve Türkçe Öğretmenleriyle İlgili Paradigmatik Bir Değerlendirme

öğretmenlerinde ise bu sayı 3'tür. Din Kültürü ve Ahlak Bilgisi öğretmenlerinde ise 2 öğretmen Almanca dilinden görev bölgemize gelmiş olup, geriye kalan bir öğretmen ise 5 yıllık görev süresi içinde Almanca öğrenememiştir.

Dil konusundaki bu eksikliğin tek sorumlusunun dil öğrenemeyen öğretmen olmadığı görüşündeyiz. Aldıkları yevmiye ile kıt kanaat geçinen öğretmenlerin bütçeleri kurs ücreti ve kursa sırasında yapacakları harcamalarla zorlayacağı açıktır. Ayrıca bu konuda öğretmeni motive edemeyen ve hiçbir zorlayıcı hüküm koyamayan idarenin de sorumluluğu olduğu kanaatindeyiz.

\section{TTK Öğretmenlerinin 2. Yabancı Dil (İngilizce) Dil Değişkenine Göre Dağılımı}

Bölgemizde görev yapan tüm İngilizce, Türkçe ile Türk Dili ve Edebiyatı öğretmenleri İngilizceden sınava girmişlerdir. Bunun yanı sıra 3 Din kültürü ve Ahlak bilgisi öğretmeninden biri de İngilizce ile göreve başlamıştır. Bu sayı toplamda 18 kişidir.

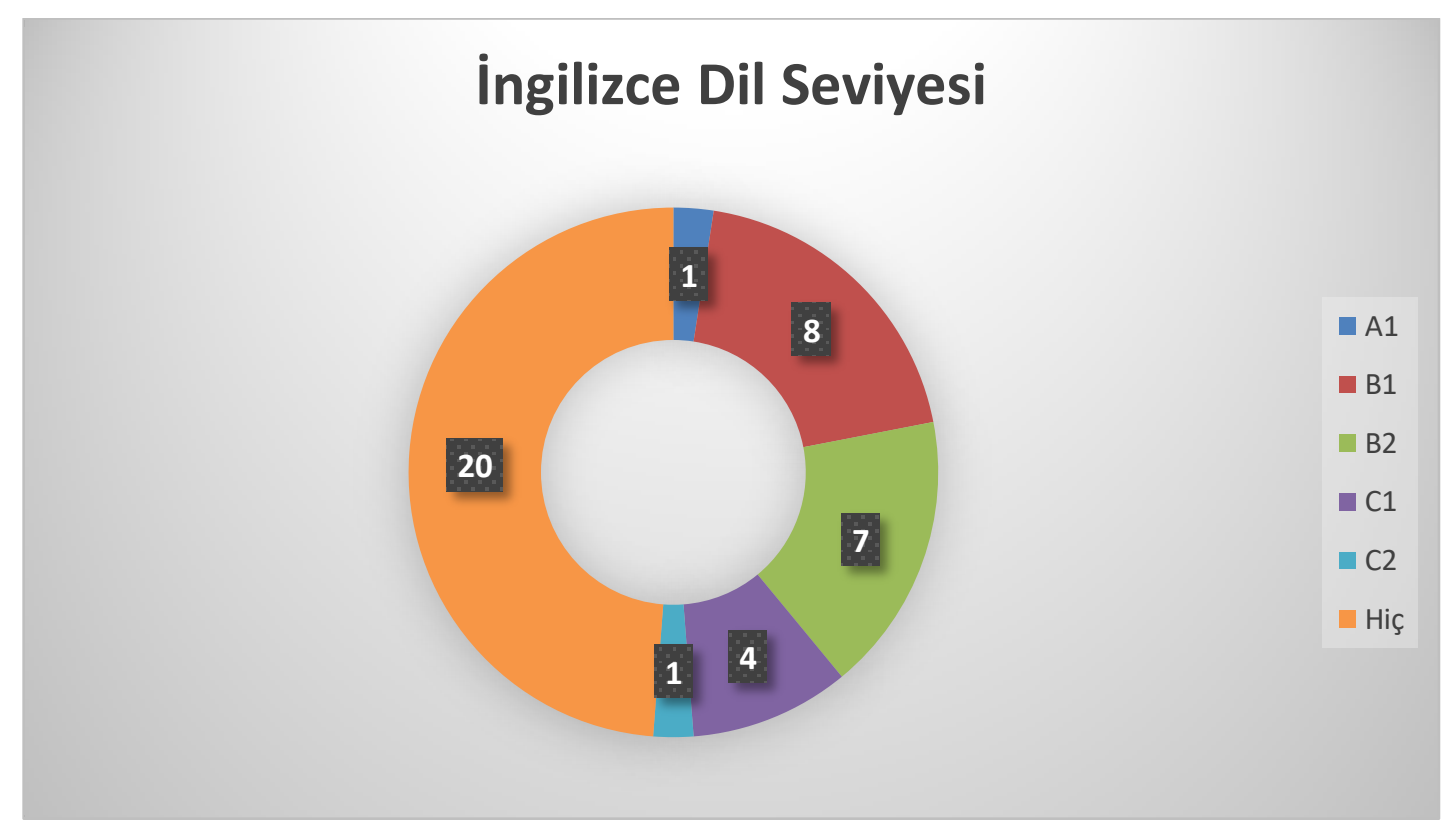

Grafik 9. TTK öğretmenlerinin 2. yabancı dil (İngilizce) değişkenine göre dağılımı

Bölgemize Almanca bilerek gelen 23 TTK (Sınıf, Almanca ve Din Kültürü ve Ahlak Bilgisi öğretmenleri) öğretmeninden sadece 2 öğretmen B1, bir öğretmen de A1 seviyesinde İngilizce bilmektedir. Geriye kalan 20 öğretmenin 2. yabancı dil bilgisi bulunmamaktadır. Bölgemizde görev yapan TTK öğretmenlerinden sadece 9'u her iki dilde en az B1 seviyesi 
Mustafa ÇAKIR - Güney Bavyera' daki Türkçe Anadili Dersi ve Türkçe Öğretmenleriyle İlgili Paradigmatik Bir Değerlendirme

olmak üzere hem Almanca hem de İngilizce bilmektedir. Bunun dışında 2 öğretmen ise iki dilin birinde en az A2 seviyesi olmak üzere hem Almanca hem de İngilizce bilmektedir.

\section{SONUÇ VE ÖNERİLER}

\section{Sonuç}

Bavyera Eyaletinin okul sistemi okul öncesi eğitim düzeyinden yükseköğretim basamaklarına kadar dünyada en gelişmiş sistemlerden biridir. 57 ülkedeki bütün okul türlerinden 15 yaşındaki öğrencilerden seçilen grupların katıldığg OECD’nin 2006 PISA (Programme for International Student Assessment) araştırmasında Bavyeralı öğrenciler Fen Bilimleri alanında 4., okuma ve matematik alanlarında 8. sırayı almışlardır. Almanya genelinde bakıldığında ise Bavyeralı öğrenciler, Saksonyalı öğrencilerin ardından ikinci sırayı almıştır ${ }^{18}$.

Alman eğitim sisteminin çocuklarımıza sağladığı imkânların yanı sıra, Türkiye ve Türk kültürü ile bağlarının canlı tutulması ve Almanca öğrenirken Türkçeyi unutmamaları için özveri ile çalışan öğretmenlerimiz farklı yerleşim birimlerinde ve birden fazla okulda $(5,6)$ görev yapmaktadir.

Öğretmenlerimizin önemli bir kısmı Türk veliler ile Alman Okul idaresi arasındaki ilişkilerde dil engelinden dolayı köprü görevi üstlenememektedirler. Bununla birlikte Türkçe ve Türk kültürü dersinden başka, kültürel etkinlikler düzenlemekte, toplumun değişik kesimlerine danışmanlık hizmeti vermektedirler (Bkz.: Çakır; Yıldız 2016).

Araştırma bulguları ile ilgili çıkarılan sonuçlar aşağıda verilmiştir. TTK dersleri bakımindan;

1. Türkçe ve Türk Kültürü Dersinin verilmesiyle ilgili uygulamanın bariyerleri ile birlikte devam etmesi halinde, ülkede yaşayan beşinci kuşak Türkiye kökenlilerin dedeleri ile veya Türkiye' deki yakınları ile Türkçe konuşamama tehlikesi vardır.

Almanya genelinde, Bavyera özelinde, yerel mülahazalar ve kısa erimli politikalar ile Türkiye kökenlilerin Türkiye ile bağı gevşetilmeye ve bu yolla Alman toplumu içinde yeni bir sosyo kültürel yapı oluşturulmaya çalışıldı̆̆ı görülmektedir.

\footnotetext{
18 Veriler 15.01.2019 tarihinde Bavyera Eyaleti Ders ve Kültür Bakanlığına ait Devlet Yatılı Okulları [Öffentliche Internatsschulen Bayern] ağ sayfasında bulunan Bavyerada Eğitim [Bildung in Bayern] https://www.internatebayern.com/bildung-in-bayern/ adresinden alınmıştır.
} 
Mustafa ÇAKIR - Güney Bavyera'daki Türkçe Anadili Dersi ve Türkçe Öğretmenleriyle İlgili Paradigmatik Bir Değerlendirme

Başkonsolosluk üzerinden verilen dersler de merkezi yönetim tarafından olmasa bile Münih belediyesi gibi yerel yönetimler ve eğitim öğretim etkinliklerinin gerçekleştirildiği kurumlardaki yöneticiler tarafından örtülü olarak engellenmektedir. Hâlbuki Türkiye'nin çabaları doğuştan Alman vatandaşlı̆̆ını kazanmış olan Türkiye kökenli çocukların daha iyi eğitim alarak sosyal refah düzeyinin artmasını sağlamanın yanı sıra, Almanya'nın geleceğine yapılmış olumlu bir katkı olarak değerlendirilmelidir.

Türkçe ve Türk kültürünün devam etmemesi sadece Türkiye için değil, Almanya için de çok dillilik ve çok kültürlülük adına önemli bir kazanımın, insan kaynağının ortadan kalkacağı anlamına gelmektedir.

2. Öğretmenlerin ankete dayalı bulgular ve yorum kısmında tespit edilen özellikleri ile ilgili olarak aşağıdaki sonuçlar çıkarılmıştır. Buna göre;

- demografik özelliklerinin hizmetin sürdürülmesinde farkındalık yaratan bir durum tespit edilememiştir. Bununla birlikte bazı okul aile birliği derneklerinden kadın öğretmen talepleri gelmektedir. Bu durumunun anılan derneklerin yöneticilerinin ağırlıklı olarak kadınlardan oluşmasından kaynaklandığı düşünülmektedir.

- $\quad$ öğretmenlerin Türkiye' de görev yaptıkları alanlara göre dağılıma bakıldığında Almanca öğretmenleri çoğunluktadır. Bunun yanı sıra sınıf öğretmeni, Türkçe öğretmeni, İngilizce öğretmeni, Türk Dili ve Edebiyatı öğretmeni, Din Kültürü ve Ahlak Bilgisi öğretmeninin görev yapmakta olduğu tespit edilmiştir. İktisatişletme alanı çıkışlı öğretmenlerin de sınıf öğretmeni olarak görev yapması öğretmen-öğrenci-aile-okul idaresi iletişimine olumsuz yansımaktadır.

- $\quad$ öğretmenlerin hizmet yılı değişkenine bakıldığında deneyimli öğretmenlerin daha başarılı oldukları gözlenmektedir. Bununla birlikte kıdemli öğretmenlerin mesleki tatmin duygusu ile ilgili sorun yaşanmaktadır.

- $\quad$ öğretmenlerinin Yurtdışı Görev Süresi değişkenine bakıldığında, ilk yılların deneyimsizliğinden ve sorunlarından sıyrılan öğretmenlerin çevreleri ile uyumunun geliştiği ve zaman içerisinde toplum lideri özelliği kazandıkları görülmektedir.

- öğretmenlerinin eğitim durumu değişkenine bakıldığında, öğretmenlerin ağırlıklı olarak lisansüstü eğitim, Almanca dil kursuna devam etme gibi çabalarının sınırlı olduğu gözlenmektedir. Bu durum öğretmenlerin görev bölgelerinin dağınık olması, ehliyet ve araç sorunu yaşanması, kalabalık aile 
Mustafa ÇAKIR - Güney Bavyera'daki Türkçe Anadili Dersi ve Türkçe Öğretmenleriyle İlgili Paradigmatik Bir Değerlendirme

yapısına sahip olunması nedeniyle ekonomik yetersizlik görülmesi gibi nedenlerden kaynaklanabilmektedir.

- $\quad$ öğretmenlerinin yabancı dil bilgisi değişkenine bakıldığında, sınıf öğretmenleri ile din kültürü dersi öğretmenlerinin Almanca dil bilgisinin yeterli olmadığ görülmektedir. Bu öğretmenlerin Almanca kursuna devam ederek kendilerini geliştirmesi, Türkiye'den Almanya'ya gelmeden önce B1 düzeyinde Almanca öğrenmesi ve bu durumlarını belgelendirdikten sonra yurt dışı göreve gönderilmesinde yarar görülmektedir.

\section{Öneriler}

Güney Bavyera'daki durum değerlendirildiğinde, sistemin "zayıf" ve "gelişmeye açık" yönlerinin "fırsatlar" ve "kazanımlar"a göre öne çıktığı görülmektedir. Öğretmenlerimizin Almanca dil bilgilerinin arzu edilen düzeyde olmaması, farklı branşlardan gelmeleri nedeniyle anadili dersini verecek özel öğretim teknikleri ile birleştirilmiş sınıflarda öğretim teknikleri açısından hizmet içi eğitime gereksinim duymaları verilen dersin "marka değerini" olumsuz etkileyen durumlar olarak öne çıkmaktadır. Bu sorun zaman içinde düzenlenecek hizmet içi eğitimlerle çözülebilecek niteliktedir.

Konuya verimlilik açısında bakıldığında bütün maliyetine rağmen ${ }^{19}$ Türkçe ve Türk Kültürü Derslerinden istendik verimin alındığı, öğretmenlerin mesleki tatminini gerçekleştirdiğini söylemek zordur. Bir yanda yerel engeller, öbür yanda Türk velilerin ilgisizliği ve dini cemaatler ile STK'lar tarafından çoğu defa öğretmen yeterliliği bilinmeyen eğitmenlerce düzenlenen hafta sonu etkinlikleri, kursları ve kültürel çalışmalar Türkçe derslerinin uzun süre devam ettirilmesi imkânını ortadan kaldıracak nedenler olarak görülmektedir. Bunun yanı sıra cami derneklerine devam eden öğrenciler ile TTK derslerine devam eden öğrenciler aynı kaynaktan gelmektedir. Bu derneklerin düzenlediği yarışmalar ile TTK dersi öğretmenlerinin etkinlikleri birlikte değerlendirildiğinde, isteğe bağlı olan TTK dersine karşı cami derneklerinin etkinlikleri, belki çocuklar tarafından değil ama velileri tarafından tercih edilmektedir. Buna ilave olarak öğretmenlerde görülen motivasyon eksikliği ve iş tatminsizliği verimlilik kaybına neden olmakta; TTK dersiyle ilişkilendirilmesi gereken misyonun gerçekleştirilmesine mani olmaktadır. Bu nedenle Türkçe öğretmeni seçiminin yanı sıra, öğretim süreçlerinin iyi analiz edilmesi ve sürecin kendi içinde etkin şekilde analizinin yapılması ve elde edilecek verilerle sürecin yönetilmesini kolaylaştıracak

\footnotetext{
${ }^{19}$ Güney Bavyera' daki Türkçe ve Türk Kültürü Dersi veren 41 öğretmenin yıllık maliyeti bir milyon Avronun üzerindedir.
} 
Mustafa ÇAKIR - Güney Bavyera' daki Türkçe Anadili Dersi ve Türkçe Öğretmenleriyle İlgili Paradigmatik Bir Değerlendirme

tedbirlerin alınması ve geleceğe yönelik insan kaynaklarının rasyonel verimlilik boyutunda planlanması önerilmektedir.

\section{KAYNAKÇA}

CEMALOĞLU, Necati; ERDEMOĞLU ŞAHİN, Dilek (2007). Öğretmenlerin Mesleki Tükenmişlik Düzeylerinin Farklı Değişkenlere Göre İncelenmesi. İçinde: Kastamonu Eğitim Dergisi. Cilt 15, No: 2, ss. 465-484.

ÇAKIR, Mustafa; YILDIZ, Cemal (2016). Almanya'daki Türk Öğretmenlerin Türkçe ve Türk Kültürü Dersine İlişkin Görüşleri. International Journal of Languages' Education and Teaching. Year 4, Issue 3, December 2016, p. 217-257.

ÇELIKKTEN, Mustafa (2005). Neden İş Analizi Yapılmalı?. İçinde: Erciyes Üniversitesi Sosyal Bilimler Enstitüsü Dergisi. Sayı: 18 Yıl: 2005/1 (127-135 s.)

FIRAT, Abdullah (2008). Eğitim Yönetiminde Paradigmalar ve Etkileri. Eğitim-Bir-Sen Basin Yayın. 15.02.2019 tarihinde http://www.ebs.org.tr/makaleler/91/11/diger-yazarlar/egitimyonetiminde-paradigmalar-ve-etkileri---abdullah-firat adresinden alınd1.

FRIEDRICHS, Jürgen (1980). Methoden empirischer Sozialforschung. 13. Basım. Opladen: Westdeutcher Verlag.

KARASAR, Niyazi (2013). Bilimsel Araştırma Yöntemi: Kavramlar, İlkeler ve Teknikler. 12. Basım. Ankara: Nobel.

ÇELİK, Vehbi (1993). Etkili Bir Okul İçin Stratejik Yönetim. Eğitim ve Bilim Dergisi. 19.02.2019 tarihinde http://eb.ted.org.tr/index.php/EB/article/view/5904 adresinden alınd1. s. 28'den aktarım: “TÜMER, S. (1993). Neden Stratejik Yönetim. Verimlilik Dergisi, Milli Prodüktivite Merkezi Yayını, 1, Ankara, ss.99-118" 
Mustafa ÇAKIR - Güney Bavyera' daki Türkçe Anadili Dersi ve Türkçe Öğretmenleriyle İlgili Paradigmatik Bir Değerlendirme

\section{EK}

\section{Öğretmen Akademik Gelişim Takip Formu}

(Gerektiğinde ilgili madde belirtilmek kaydı ile ek kâğıt kullanılabilir.)

1 - Bildiğiniz yabancı dillerin seviyesi (YDS, TOEFL, Goethe Enstitüsü Sertifikaları)

2- Münih Eğitim Ataşeliği görev bölgesine geldikten sonra edinilen hizmet içi veya seminer sertifikaları Doktora)

3- Görev süresinde edinilen unvanlar / devam edilen akademik eğitimler (YL,

4- Bilimsel yayınları ve araştırmaları (tez, makale, bildiri, kitap v.b. (Ek liste yapılabilir))

5 - Görev süresinde bulunduğu komisyon çalışmaları (Devam eden veya tamamlanmış)

6 - Görev süresinde organize ettiği milli bayramlar, kutlama etkinlikleri

7 - Görev süresinde velilerle yaptığı etkinlikler (veli toplantıları dâhil)

8 - Görev süresinde yaptığı diğer kültürel ve sanatsal etkinlikler veya düzenlediği organizasyonlar (Ek kâğıt kullanılabilir).

Tarafımca yukarıda vermiş olduğum bilgilerin doğruluğunu ve bilgilerin hatalı olması durumunda doğacak yükümlülüğü kabul ediyorum. Bu bilgilerde var olan bir hata veya eksiklik nedeniyle uğrayacağım maddi ve manevi zarardan dolayı herhangi bir hak iddia etmeyeceğimi beyan ederim.

Tarih:

İmza: 